\title{
1 Mobilome and genetic modification of bifidobacteria
}

2

3 Simone Guglielmetti ${ }^{1}$, Baltasar $\mathrm{Mayo}^{2}$, Pablo Álvarez-Martín ${ }^{3}$

4

$5 \quad{ }^{1}$ Dipartimento di Scienze e Tecnologie Alimentari e Microbiologiche, Sezione di

6 Microbiologia Industriale, Università degli studi di Milano, Via Celoria 2, 20133-

7 Milan, Italy

$8 \quad{ }^{2}$ Departamento de Microbiología y Bioquímica, Instituto de Productos Lácteos de

9 Asturias, Consejo Superior de Investigaciones Científicas, (IPLA-CSIC), Carretera de

10 Infiesto, s/n, 33300-Villaviciosa, Asturias, Spain

$11{ }^{3}$ BioAnalytical Science Department, Nestec Ltd., Nestlé Research Centre, CH-1000

12 Lausanne 26, Switzerland

13

14 Methodology: Med-Line, SciVerse (Science-Direct), Scopus

15 Key words: Bifidobacterium, bifidobacteria, probiotics, plasmid, vector, genetic

16 engineering

17

18

19

20

21

22

Correspondence to:

B. Mayo, Departamento de Microbiología y Bioquímica, Instituto de Productos

Lácteos de Asturias, Consejo Superior de Investigaciones Científicas, (IPLA-CSIC),

Carretera de Infiesto, s/n, 33300-Villaviciosa, Asturias, Spain

Phone number: +34985892131

Fax numer: +34985892233

e-mail address: baltasar.mayo@ipla.csic.es 


\section{Abstract}

Until recently, proper development of molecular studies in Bifidobacterium species has been hampered by the growth difficulties, because of their exigent nutritive requirements and oxygen sensitivity, and a lack of efficient genetic tools. These studies, however, are critical to uncover the cross-talk between bifidobacteria and their hosts' cells, and also to prove unequivocally the supposed beneficial effects they provide through endogenous bifidobacterial populations or after their ingestion as probiotics. The genome sequencing projects of different bifidobacterial strains have provided a wealth of genetic data, which will be of much help to decipher the molecular basis of the physiological properties of bifidobacteria. To this end, the purposeful development of stable cloning and expression vectors based on robust replicons -either from temperate phages or resident plasmids- is still needed. This review addresses the current knowledge on the mobile genetic elements of bifidobacteria (prophages, plasmids, and transposons) and summarizes the different types of vectors already available, together with the transformation procedures for introducing DNA into the cells. It also covers recent molecular studies performed with such vectors and incipient results on the genetic modification of these organisms, establishing the basis that would allow the use of bifidobacteria for future biotechnological applications.

\section{General introduction}

The members of the genus Bifidobacterium are anaerobic, fermentative bacteria, high $\mathrm{G}+\mathrm{C}$, Gram-positive bacteria belonging to order Bifidobacteriales inside the phylum Actinobacteria (Scardovi, 1986). Bifidobacterial species form a coherent phylogenetic group showing over 93\% similarity of the $16 \mathrm{~S}$ rRNA sequences among 
them. At present, more than 40 species are included in the genus Bifidobacterium (http://old.dsmz.de/microorganisms/bacterial_nomenclature info.php?genus=Bifidoba cterium), of which B. adolescentis, B. angulatum, B. breve, B. bifidum, B. catenulatum, B. dentium, B. longum, and B. pseudocatenolatum are dominant Bifidobacterium species in the human gastrointestinal tract (GIT) (Fanaro et al., 2003; Mueller et al., 2006). These and B. animalis subsp. lactis, the typical species isolated from functional foods (Masco et al., 2005), are therefore the first target for health-related studies. Bifidobacteria are considered to exert a vast array of beneficial health effects, including the establishment of healthy microbiota in infants, competitive exclusion against intestinal pathogens, and modulation of the immune functions (Leahy et al., 2005; Turroni et al., 2009). In humans, bifidobacteria represent up to $90 \%$ of the total gut microbiota in breast-fed babies (Fanaro et al., 2003; Turroni et al., 2012) and up to $5 \%$ in healthy adults (Mueller et al., 2006; Claesson et al., 2011). The colonization of human intestinal tract by bifidobacteria starts soon after birth and lasts all lifelong. Thus, unsurprisingly bifidobacteria have become a common component of probiotic products designed for human or animal consumption (Tuohy et al., 2003; Leahy et al., 2005; Parvez et al., 2006). Probiotic products represent a strong growth area within the functional foods market and are currently having a significant economic impact on the dairy sector. However, 'long-term exploitation of probiotics as health promoters is dependent on several factors, including sound, scientifically-proven clinical evidence of health-promoting activity, accurate consumer information, effective marketing strategies, and, above all, a quality product that fills consumer expectations' (Stanton et al., 2001). While clinical evidence for the purported beneficial effects is rapidly accumulating (Tuohy et al., 2003; Leahy et al., 2005; Guglielmetti et al., 2011; Guglielmetti et al., 2011; Ishikawa et al., 2011), there still is a lack of fundamental 
knowledge on the molecular mechanisms by which bifidobacteria interact with other bacteria and their hosts, while contributing to their health and well-being (Kullen and Klaenhammer, 2000; Ventura et al., 2009).

\section{Genetics of bifidobacteria}

Compared with other microbes of industrial importance, the genetics of bifidobacteria is poorly understood (Ventura et al., 2004). Bifidobacteria are difficult to handle in the laboratory because they are exigent microorganisms demanding for growth rich media and requiring strict anaerobic conditions (Scardovi, 1986). In addition, genetic studies have further been hampered by a lack of appropriate bacterial replicons (of either plasmid or phage origin), with which to construct suitable genetic tools. Moreover, until recently, bifidobacteria were considered recalcitrant to transformation, and genetic engineering techniques were simply unknown. In the last decade, whole genome sequencing has revolutionized the genetic, biochemical, and molecular biological research in bacteria and in many higher organisms, constituting an essential step for generating primary genetic information for downstream functional applications, such as comparative genomics, transcriptomics, and/or proteomics, which in turn can address fundamental and applied questions. Specifically, operons and genes encoding several cell envelope-associated structures, such as exopolysaccharides (EPS) (Schell et al., 2002; Barrangou et al., 2009; Ventura et al., 2009b), fimbriae-like glycoproteins (Schell et al., 2002; Ventura et al., 2009b), serpin-like protease inhibitors (Ivanov et al., 2006; Turroni et al., 2010), adhesins (Guglielmetti et al., 2008b), and pilus-like structures (Foroni et al., 2011; O’Connell Motherway et al., 2011a), have been identified. In addition, genes dealing with diverse stresses that bifidobacteria face in their environment (acid, bile), genes encoding 
101 adaptive functions to the intestinal niche, or others contributing to ecological fitness

102 have also been identified (Schell et al., 2002; Sela et al., 2008; Barrangou et al., 2009;

103 Kim et al., 2009). Concerning the adaptation to intestinal environmental, largely the

104 best studied bifidobacterial strain is $B$. breve UCC2003, thanks to the molecular and

105 functional characterization of many genetic loci, which have been identified in its

106 genome (O'Connell et al., 2008; Zomer and van Sinderen, 2010; O'Connell Motherway

107 et al., 2011a; O'Connell Motherway et al., 2011b; Pokusaeva et al., 2011; Fanning et

108 al., 2012; Ruiz et al., 2012).

109 Up till now, the genome sequences publically available of 17 Bifidobacterium

110 strains belonging to five species, namely B. adolescentis, B. animalis subsp. lactis, $B$.

111 bifidum, $B$. dentium, and B. longum of both infantis and longum subspecies, have all

112 been concluded and analysed (http://www.ncbi.nlm.nih.gov/genomes/lproks.cgi). In

113 addition, many other Bifidobacterium genome projects are in progress worldwide and,

114 due to the progressive cost reduction of the sequencing technologies, this list is

115 exponentially growing. To manage this enormous wealth of genetic data and prove

116 unequivocally the biological role of each particular operon or gene, cloning,

117 expression, knock-out, and transfer of the determinants are needed. To these aims,

118 suitable vectors and other genetic tools based on the replication units and insertional

119 machinery of phages, plasmids and/or transposons are essential.

120

\section{The mobilome of bifidobacteria}

Genomes are the result of the adaptive evolution of microorganisms to their

123 ecological niche (Ventura et al., 2007). In this context, various genetic events, such as

124 gene duplication, horizontal gene transfer (HGT), gene decay, and chromosomal

125 rearrangements, have determined the shape of bacterial genomes. As suggested by 
126 Philippe and Douady (2003), plasmids, bacteriophages (phages), and transposons are

127 considered major agents for shaping the bifidobacterial genomes through horizontal

128 gene transfer (HGT) processes. The above mentioned mobile genetic elements, as well

129 as others, such as group II introns and jumping genes, constitute what has recently been

130 defined as the mobilome (Frost et al., 2005; Siefert, 2009).

\subsection{Plasmids of bifidobacteria}

Plasmids are extra-chromosomal, autonomously replicating genetic elements

134 found in bacteria, archaea, and eukaryotic cells. Despite their independent replication,

135 plasmids make use of cellular enzymes to ensure both replication and maintenance

136 (Hayes, 2003). Plasmids display an enormous diversity of features, such as size, host

137 range, and the repertoire of genes that they carry. By definition, plasmids do not

138 encode essential genes for growth, nonetheless they can provide a wide variety of

139 phenotypes to the cells that harbour them, including antibiotic resistance, bacteriocin

140 production, virulence and pathogenesis or degradation of complex and recalcitrant

141 (toxic) compounds found in some ecosystems. They can also encode for the ability to

142 use carbohydrates and/or protein substances as a source of carbon and energy (Thomas

143 et al., 2004). All these properties have endowed plasmids with the title of primarily

144 adaptative entities (Siezen et al., 2005). Apart from the traits with an impact on host

145 physiology and ecology, important characteristics of plasmids include copy number

146 (low, medium, high), host range (narrow, broad), and capability to spread (conjugation,

147 mobilization) (Hayes, 2003). Small plasmids (i.e. smaller than 15-20 kb in size) often

148 do not encode any selectable trait and are therefore denominated "cryptic". It seems,

149 however, plausible to presume that they simply benefit its host by promoting

150 recombination and, consequently, enhance the ecological adaptability of the bacterial 
151 population (Guglielmetti et al., 2007a; Thomas et al., 2004). Plasmids can be,

152 consequently, depicted as accessory and/or adaptive gene pools shared by bacteria.

153 Analyses of bifidobacteria have indicated that extrachromosomal elements are

154 scarcer than in other intestinal bacterial species (Sgorbati et al., 1982; Iwata and

155 Morishita, 1989; Park et al., 1997) and, where found, they have a size generally smaller

156 than $15 \mathrm{~kb}$. Strains from the species B. longum subsp. longum (hereafter B. longum, if

157 not differently specified), B. globosum, B. asteroides, and B. indicum seem to harbour

158 more plasmids than those from other species (Sgorbati et al., 1982). At present, the

159 nucleotidic sequence of more than 30 bifidobacterial plasmid molecules is available in

160 GenBank (Table 1; http://www.ncbi.nlm.nih.gov/sites/entrez/). The majority of these

161 molecules (up to 19) were isolated from B. longum strains, which includes pMB1

162 (Rossi et al., 1996), the first plasmid to be analysed at a molecular level from a

163 member of this genus. Three other plasmids have been characterized from strains of $B$.

164 breve, two from B. asteroides and B. bifidum, and single plasmids have been analysed

165 from strains of B. catenulatum, B. pseudocatenulatum, and B. pseudolongum subsp.

166 globosum. The obtained sizes of the studied plasmids show a range between $1.8 \mathrm{~kb}$ for

$167 \mathrm{pMB} 1$ to $10.2 \mathrm{~kb}$ for pNAC3. In most cases, strains harbour a single plasmid, except

168 for three strains of B. longum in which two different plasmid molecules were identified

169 (Table 1). In addition, B. longum NAL8 and B. longum FI10564 have been reported to

170 contain three different plasmids each. The significance of these autonomously-

171 replicating DNA elements in bifidobacteria remains unclear, since no obvious

172 phenotypic traits have been associated to plasmids, except for the production of the

173 bacteriocin bifidocin B by B. bifidum NCFB 1454, which was associated to a $8 \mathrm{~kb}$

174 plasmid (Yildirim et al., 1999). Nevertheless, this plasmid has never been sequenced or

175 characterized further. More recently, a further plasmid of this species (pBIF10) has 
176 been found to contain tet $Q$, a gene encoding a ribosome protection protein providing

177 tetracycline resistance (DQ093580).

178 The basic biology of bifidobacterial plasmids remains poorly understood and most

179 of the information derive from in silico investigation. Indeed, the mode of replication

180 has been experimentally analysed for only a few of them (Moon et al., 2009; Park et

181 al., 2008; Guglielmetti et al., 2007b; Lee and O'Sullivan, 2006; Corneau et al., 2004;

182 O'Riordan and Fitzgerald, 1999; Park et al., 1999). Furthermore, dissection of open

183 reading frames (ORFs) and analysis of untranslated sequences and structures have been

184 undertaken for only two plasmids: pBC1 (Álvarez-Martín et al., 2007a) and pCIBA089

185 (Cronin et al., 2007). Sequence comparison suggests that most bifidobacterial plasmids

186 probably replicate by means of a rolling-circle mechanism, with the exception

187 represented by eight plasmids that appear to use the theta-replicating mode (Table 1;

188 Moon et al., 2009; Álvarez-Martín et al., 2008; Cronin et al., 2007; Klijn et al., 2006;

189 Lee and O'Sullivan, 2006; Rossi et al., 1996). Phylogenetic analysis of their replication

190 (Rep) initiator proteins revealed that Bifidobacterium plasmids could be clustered into

191 six different groups (Table 1 and Fig. 1). Homology of bifidobacterial Rep proteins has

192 shown that, in some cases, their closest relatives are found in plasmids from

193 phylogenetically distant bacterial groups (Álvarez-Martín et al., 2007b; Guglielmetti et

194 al., 2007b). For instance, Rep protein of plasmid pBIF10 from B. bifidum M203049

195 (type $I V$ ) is strictly related with the replication proteins of plasmids commonly

196 harbored by the Cytophaga-Flavobacterium-Bacteroides group of Gram-negative

197 bacteria. The same plasmid also contains two other DNA regions, respectively of 1966

198 and 2569 bp displaying strong similarity with genetic regions of Bacteroides intestinal

199 strains (DQ093580). The former region includes mobilization genes $m o b A$ and $m o b B$,

200 while the latter comprises tetQ gene (Fig. 2). These similarities leave to suppose that 
201 plasmid pBIF10 could have been relatively recently acquired by strain B. bifidum

202 M203049 from Bacteroides thorough horizontal DNA transfer.

203 More surprisingly, the Rep protein encoded by plasmid p4M from $B$.

204 pseudocatenulatum VMKB4M (type VI) displays its highest level of similarity to the

205 replication initiator protein of the eukaryotic circoviruses/cicloviruses, a feature that is

206 unprecedented in any known bacterial plasmid (Gibbs et al., 2006).

207 Upstream of the Rep protein, Bifidobacterium plasmids contains non-coding

208 regions characterized by tandem direct and inverted repeats sequences, in an

209 organization that resembles the so-called DNA iteron structures observed in the origin

210 of replication of some theta and rolling circle replicating plasmids (del Solar et al.,

211 1998). The tandem repeat organization is similar in all plasmids but sequences of the

212 repeats are variable, thus, conferring specific interaction between Rep proteins and

213 DNA sequences.

214 Differences in nucleotide sequences and gene organization have been encountered

215 among the 30 known bifidobacterial plasmids, leading to the identification of 13

216 different modular structures, represented by the genetic maps of characteristic plasmids

217 shown in Fig. 2. Apart from Rep, many plasmids contains accessory ORFs encoding

218 hypothetical proteins, some of which, such as the mobilization-like proteins (Fig. 2),

219 may be involved, together with their accompanying oriT sequences, in plasmid spread.

220 In a few bifidobacterial plasmids are also present putative genes encoding non-

221 essential proteins, such as OrfX and CopG, which are involved in the control of

222 replication, copy number and/or plasmid stability (Álvarez-Martín et al., 2007a; del

223 Solar et al., 1998).

224 Finally, it should be mentioned that whole genome analyses of Bifidobacterium

225 strains are revealing the presence of integrated plasmid remnants in the chromosome, 
such as those discovered in B. longum NCC2705 (Schell et al., 2002) and F8 (GenBank Acc. No. FP929034).

\subsection{Phages of bifidobacteria}

Phages are widely distributed among eubacteria, where they are thought to

231 influence the genomic evolution and adaptive capabilities of their hosts (Canchaya et al., 2003). The first report of Bifidobacterium phages dates back to 1966, when they were detected in rumen (Youseff et al., 1966). However, in this work the morphology and other characteristics of the phage particles were unreported. The work of Youse et al. was followed by an electron microscopy observation of a lytic phage from the socalled B. ruminale (today reclassified as B. thermophilum) strain RU271 by Matteuzzi and Sozzi (1970). Further pioneering reports include that of Sgorbati et al. (1983), where inducible prophages from strains of B. longum were released by mitomycin C and further characterized by electron microscopy. However, no further studies on

240 bifidobacterial phages appeared until the analysis of whole genomes. Three highly

241 related prophage-like elements have been reported to be present in the genome of $B$. breve UCC2003, B. longum NCC2705, and B. longum DJO10A (Ventura et al., 2005).

243 These elements, designated Bbr-1, Bl-1, and Blj-1 respectively, share nucleotide and organization homology with double-stranded DNA bacteriophages infecting low $\mathrm{G}+\mathrm{C}$

245 Gram-positive bacteria, arguing for a common evolution of phages within the GIT 246 ecosystem (Ventura et al., 2005). The Blj-1 prophage is $36.9 \mathrm{~kb}$ long and is excised

247 from the chromosome when B. longum DJO10A is exposed to mitomycin C or 248 hydrogen peroxide (Ventura et al., 2005). Thus, Blj-1 appears to constitute the first 249 inducible prophage whose sequence is entirely known. In contrast, Bbr-1 and B1-1 250 elements are not inducible, suggesting they may represent non-functional prophages. 
251 Though defective, they may still constitute functional satellite phages, whose mobility

252 depends on helper phages in a similar manner to that described for the cryptic

253

254

255

256

257

258

259 mycophages Rv1 and Rv2 (Hendrix et al., 1999). All three bifidobacterial prophages are integrated in a tRNAMet gene, which had not previously been shown to act as an attB site in Gram-positives (Campbell, 1992). Analysis of the distribution of this integration site in bifidobacterial species has revealed that $a t t B$ sites are well conserved. In addition, in the genome of B. longum subsp. infantis ATCC 15697 and those of B. animalis subsp. lactis DSM10140 and B1-04, prophage genes have also been encountered (Sela et al., 2008; Barrangou et al., 2009), although these remnant elements are not adjacent to tRNAMet sequences. The use of conserved attB sequences and their associated int genes might allow the construction of efficient recombination modules analogous to the Streptomyces integrative plasmid pSE211 (Brown et al., 1990). This module may represent an ideal source for integration systems, enabling future development of food-grade, single copy integration of foreign DNA at specific sites within the bifidobacterial chromosome without disturbing host functions. Similar systems have been developed for lactic acid bacteria, such as lactobacilli (Martín et al., 2000), and for high G+C bacteria, such as Streptomyces and Mycobacterium (Combes et al., 2002).

\subsection{Transposons and insertion sequence (IS) elements in bifidobacteria} Transposons and IS elements are mobile genetic units that move from one to another position in the genome by a process referred to as transposition. Transposition occurs via one of two mechanisms: cut-and-paste transposition or replicative transposition (Roberts et al., 2008), leaving, respectively, one copy on the target DNA or two copies on both donor and target DNA. Both transposons and ISs are potent, 
broad spectrum mutators contributing to the shape of the function, structure and

277 dynamics of genes and genomes (Philippe and Douady, 2003). Transposons and ISs

278 can be converted into powerful genetic tools, with which to explore the functionality of

279 genes. In addition, transposons integrating at preferred, neutral sites can be used for

280 genetic modification of bacteria. Sixteen IS elements of five classes have been reported

281 to be spread in the B. longum NCC2705 genome (Schell et al., 2002). Although present

282 at similar numbers in the genome of all other strains analyzed, ISs have not been

283 considered in other works. An IS of 1047 bp long was identified in the upstream region

284 of the tetracycline resistant gene tet $(\mathrm{W})$ found on the chromosome of $B$. longum $\mathrm{F} 8$

285 (Kazimierczak et al., 2006). A similar IS of 1163 bp was also found to interrupt the

286 structural tet $(\mathrm{W})$ gene in the susceptible B. longum M21 strain (Ammor et al., 2008).

287 The $\operatorname{tet}(W)$ gene is also located in the chromosome of the largely diffused commercial

288 probiotic strain $B$. animalis subsp. lactis $\mathrm{BB} 12$ and was found to be adjacent to a

289 transposase gene (genes BIF_01560 and BIF_02030 of the annotated genome of strain

290 BB12; Garrigues et al., 2010). However, analysis of the flanking DNA sequences

291 shows that the $\operatorname{tet}(W)$ gene should not be contained in a functional mobile element.

292 The spreading process of the ISs involves excision and integration into a new

293 place, at which position a short nucleotide duplication is usually found. Interestingly,

294 five out of the six bp sequences duplicated in F8 (CAATGC) seem to mirror the $5 \mathrm{bp}$

295 duplication in M21 (GTTAC) (B. Mayo, unpublished), suggesting the presence of

296 active insertion sites in bifidobacterial genomes.

297 Recently, Fukiya et al. (2010) characterized an insertion sequence-like element of

298 the IS200/IS605 family, which was inserted into a 5.0-kb pKJ50-like plasmid resulting

299 in the size-increased cryptic plasmid pBK283 from B. longum strain BK28. The

300 element, named ISBlo15, was 1593 bp in length and contained a single ORF encoding 
301 a putative transposase, $\operatorname{tn} p B$ (Fig. 2). The same authors also reported that sequences

302 similar to ISBlo15 are widely distributed among the nine Bifidobacterium species they

303 tested.

304 Finally, a copy of the transposon Tn5432, which encodes resistance to

305 erythromycin and clindamycin, has been identified in several B. thermophilum strains

306 isolated from pig faeces (van Hoek et al., 2008). Tn5432 was first isolated from

307 Corynebacterium xerosis and rescued copies on plasmids were shown to be able to

308 transpose in Corynebacterium glutamicum causing several mutations (Tauch et al.,

309 1995). The transposition ability of Tn5432 from B. thermophilum remains however to

310 be determined.

311 Knowledge on Bifidobacterium transposons and ISs is strongly needed, since they

312 can bring to the development of high-efficiency transposon mutagenesis systems that

313 could greatly facilitate the molecular study of bifidobacteria. However, tools for

314 bifidobacteria based on these elements are yet not available.

315 Finally, a new mobile genetic element has been described in B. longum (Schell et

316 al., 2002; Lee et al., 2008), named mobile integrase cassette (MIC). MIC elements are

317 constituted by a conserved 20 bp palindrome sequence and two insertion sequences

318 separated by three contiguous but different xerC integrase genes (Lee et al., 2008).

319 Interestingly, one MIC of the strain B. longum DJO10A was shown to be active during

320 the adaptation of B. longum DJO10A to in vitro fermentation conditions (continous

321 growth up to about 1000 generations) (Lee et al., 2008).

324 Some natural bifidobacterial plasmids have provided the basis for the construction 325 of Escherichia coli-Bifidobacterium shuttle vectors, mostly resulting from the direct 
cloning of whole plasmids into an E. coli vector containing selectable antibiotic

327 resistance genes such as spectinomycin, erythromycin and chloramphenicol (Álvarez-

328 Martín et al., 2008; Guglielmetti et al., 2007b; Klijn et al., 2006; Lee and O’Sullivan,

329 2006; Park et al., 1999; Rossi et al., 1996, 1998; Matsumura et al., 1997; Missich et al.,

330 1994; Table 13.2). In this way, the plasmid pBC1 from B. catenulatum L48 has been

331 used for the construction of a series of E. coli-Bifidobacterium shuttle vectors with

332 innovative characteristics such as the presence of a tetracycline resistance gene of

333 bifidobacterial origin $[\operatorname{tet}(\mathrm{W})]$ and the cloning of the $\beta$-galactosidase complementing

334 peptide gene for a convenient blue/white screening of recombinant clones in E. coli

335 (Álvarez-Martín et al., 2008). The functionality of the vectors was further checked by

336 cloning and overexpression of an $\alpha$-1-arabinofuranosidase gene from B. longum B667

337 in E. coli and Bifidobacterium strains.

338 As plasmid maintenance constitutes a major problem for vector utilization,

339 González Vara and co-workers studied the segregational and structural stability of

340 pMB1-derived constructs in B. animalis by continuous culture (González Vara et al.,

341 2003). These authors reported a high correlation between instability and plasmid size,

342 while no major deletions and rearrangements were observed. However, some

343 constructs did not behave as expected (González Vara et al., 2003), a result that agrees

344 with observations by other authors (Álvarez-Martín et al., 2007a), suggesting that

345 beyond plasmid size, secondary structure of the constructs may further influence 346 stability.

347 It is worth noting that in spite of a limited knowledge of plasmid biology, a

348 number of vectors for heterologous expression of desirable foreign genes have already

349 been developed. As an example, the reporter vector pMDY23 expresses the gusA gene

350 of E. coli (Klijn et al., 2006); vector pBES2 has been used to express the $\alpha$-amylase 
gene of B. adolescentis in B. longum (Rhim et al., 2006); pBLES100 (Matsumura et al.,

352 1997) has been employed for the expression of the Salmonella flagellin gene (Takata et

353 al., 2006); and pBV22210 has been used to express the anticancer protein endostatin

354 (Xu et al., 2007).

355

\section{Genetic modification of bifidobacteria}

Since the mid-eighties, research efforts have focused on establishing effective protocols for the genetic modification of bifidobacteria. Currently,

electrotransformation (electroporation) of bifidobacteria by plasmid DNA is commonly being reported, whereas little or nothing is known about other recombinant DNA technologies such as conjugation. In fact, the members of the genus Bifidobacterium have traditionally been considered refractory to efficient and reproducible genetic manipulation. Potentially, several factors can contribute, to various extents in different strains, to bifidobacterial recalcitrance for acquiring exogenous DNA: (i) the presence of a thick (multi-layered) and complex cell wall (Fischer, 1987), (ii) intracellular restriction/modification barriers (Hartke et al., 1996; Schell et al., 2002; Yasui et al., 2009), and (iii) sensitivity to environmental stresses (principally oxygen) during preparation of competent cells and transformation.

Full exploitation of genomic data requires the use of general and specialized vectors for gene overexpression, integration, knock-out, and gene expression studies.

371 Such molecular studies can substantiate the wide use of bifidobacteria as probiotic by

372 explaining the molecular mechanisms governing the interaction with the host. In

373 addition, bifidobacteria have recently been appointed as biotechnological agents for in

374 situ production and delivery of therapeutic compounds, such as antigens (for live

375 vaccine development) and tumour-suppressing substances (Fujimori, 2006; Xu et al., 
2007), and as a means of increasing beneficial detoxifying activities into the

377 gastrointestinal tract (Park et al., 2007). Traditional and new applications, therefore,

378 require utilization of robust genetic tools and improved genetic transformation

379 techniques.

380

\subsection{Genetic transformation by electroporation}

The first scientific proof of genuine genetic transformation of Bifidobacterium

dates back to 1994, when Missich and collaborators introduced by electroporation pRM2 (Missich et al., 1994), a derivative of the small B. longum cryptic plasmid

pMB1 (Sgorbati et al. 1982), into a cured B. longum strain that originally harboured the plasmid pMB1. The small theta replicating plasmid pMB1 represents, so far, the replicon most commonly used to construct Bifidobacterium vectors (Missich et al., 1994). The protocols available for preparing electrocompent cells and subsequent electroporation are based mainly on the comprehensive studies by Argnani et al. (1996) and Rossi et al. (1997), who considered and optimized several conditions such as

391 growth medium, washing solutions, incubation temperatures, and voltage.

\subsubsection{Preparation of electro-competent cells}

The preparation of electro-competent bacterial cells consists in weakening the cell

397 bacterial cells in the exponential growth phase, growth in presence of high sugar

398 concentration, osmotic stabilizers in washing and electroporation buffers, or

399 maintaining cells at low temperature. 

uptake, numerous studies have reported the importance of harvesting bacterial cells at a

402 specific stage of their growth. Some studies showed that bifidobacteria could be 403 effectively transformed only when they were in the early exponential phase $\left(\mathrm{OD}_{600 \mathrm{~nm}}\right.$ 404 0.2-0.4) (Missich et al., 1994; Argnani et al., 1996; Rossi et al., 1997), whereas 405 efficiencies dropped for older cells, reaching zero for cells from the stationary growth 406 phase (Rossi et al., 1997). In contrast, other researchers have observed maximal 407 transformation efficiency with cells in the middle to late log phase. For instance, 408 Matsumura et al. found that with the vector pBLESS100 the transformation efficiency 409 of B. longum 105-A was about one order of magnitude higher when cells were 410 approaching the stationary phase as compared to early-log phase (Matsumura et al., 411 1997). Similarly, in more recent studies, midlogarithmic-phase cells were used (optical 412 density at $600 \mathrm{~nm} 0.5$ to 0.7 ) to effectively transform different Bifidobacterium species 413 (MacConaill et al. 2003; Cronin et al., 2007; Sangrador-Vegas et al., 2007; Álvarez 414 Martín et al., 2008).

415 Growth media. The addition to the growth medium of sugars in high

416 concentrations is traditionally recognized as an effective strategy to improve the 417 transformation yield by affecting the composition of the cell wall. Argnani and 418 collaborators (1997) cultivated the cells in MRS broth supplemented with $0.5 \mathrm{M}$ 419 sucrose and washed them in a buffered sucrose solution at the same concentration. 420 Rossi et al. (1996) showed a 100-fold increase in transformation efficiency when 421 Bifidobacterium cells were grown in Iwata medium (IM) supplemented with raffinose $4220.3 \mathrm{M}$ or, especially, $16 \%$ Actilight ${ }^{\circledR} \mathrm{P}$, as compared with cells grown in IM broth with 423 or without glucose. Actilight ${ }^{\circledR} \mathrm{P}$ is a commercial product comprising a mix of short424 chain fructooligosaccharides (1-kestose, nystose, and fructosylnystose; FOS), which 
are metabolised by bifidobacteria and may protect cells from stress (Guglielmetti et al., 2008a). Using this sugar product in a growth broth and washing buffer can thus improve transformation efficacy by preserving the cells' physiological condition during the preparation of competent bifidobacteria. This statement has been recent confirmed in a study, in which the use of $16 \%$ FOS or $10 \%$ GOS allowed the transformation of B. bifidum and B. asteroides, two bifidobcaterial species known for their recalcitrance for acquiring exogenous DNA (Serafini et al., 2012). of bacterial cells before electroporation at $4{ }^{\circ} \mathrm{C}$ in an electroporation buffer composed of $0.5 \mathrm{M}$ sucrose, $1 \mathrm{mM}$ ammonium citrate, $\mathrm{pH}$ 6, significantly improved the transformation efficiency of bifidobacteria. Argnani et al. (1997) suggested that in the conditions they had established, the presence of low-molarity ammonium citrate (more than HEPES and phosphate buffers) as the osmotic stabilizer may support the right degree of cell autolysis without limiting cell viability, resulting in improved cell wall permeability for exogenous DNA. In addition, Rossi and collaborators showed the

440 importance of the incubation step in the electroporation buffer at $0^{\circ} \mathrm{C}$ overnight (Rossi et al., 1997). Their electroporation buffer, named KMR, was composed of $\mathrm{KH}_{2} \mathrm{PO}_{4} 5$ $\mathrm{mM}, \mathrm{MgCl}_{2} 1 \mathrm{mM}$ and raffinose $0.3 \mathrm{M}, \mathrm{pH} 4 \cdot 8$. However, the higher salt concentration of the KMR buffer may favour arcing events during the electrical discharge (S.

444 Guglielmetti, unpublished).

\subsubsection{Efficiency of electro-transformation in bifidobacteria}

448 extremely low and constitutes the main limitation on successfully applying traditional

449 genetic manipulation strategies to members of this genus. Wide variation in 
transformation efficiencies have been reported in the literature, ranging from about $10^{\circ}$ (e.g., Rossi et al., 1997) to more than $10^{6}$ (e.g., Tanaka et al., 2005) transformants per

$452 \mu \mathrm{g}$ of recombinant DNA (Table 2). Besides the protocols adopted for preparing

453 competent cells and subsequent electroporation, considerable differences can be

454 obtained depending on the strain under study (see Table 2). Nonetheless, valuable

455 progress has recently been made in improving transformation rates, thanks to studies

456 on the restriction/modification systems of bifidobacteria, which have been shown to be

457 the main obstacle in the acquisition of foreign DNA by these bacteria.

458

459

\subsubsection{Optimization strategies for the electro-transformation of bifidobacteria}

To improve efficiency it is crucial to preserve cell viability during electroporation. One main reason for cell mortality during these experiments is oxidative stress. To overcome this problem, Park and colleagues added Oxyrase ${ }^{\circledR}$, and enzyme system removing oxygen from its environment, to the incubation buffer after the electric pulse was given to the competent cells. This strategy allowed B. longum MG1 to transform at 100-fold improved electroporation efficiency (Park et al., 2003).

In general, DNA introduced into bacteria by electroporation is more vulnerable to restriction nucleases than that transferred by conjugation or natural transformation. This is particularly important for bifidobacteria, whose perhaps most immediate obstacle to acquiring exogenous DNA are their restriction/modification (R-M) systems. DNA R-M gene clusters coding for methyltransferases and restriction enzymes can be recognized in all sequenced bifidobacterial genomes, and to date several proven or potential R-M systems belonging to either Type I, II, and IV have already been identified (Roberts, 1980; Hartke et al., 1996; Schell et al., 2002; Lee et al., 2008; O'Connell-Motherway et al., 2009; Yasui et al., 2009; http://rebase.neb.com/rebase). 
475 Based on the above, several studies have reported a significant increase in

476 transformation efficiency when transformed DNA has been isolated from

477 Bifidobacterium instead of E. coli (Rossi et al., 1997; Rossi et al., 1998; O’Connell-

478 Motherway et al., 2009; Yasui et al., 2009). For instance, Rossi et al. (1998), found that

479 only vector DNA prepared from bifidobacteria could successfully transform some

480 strains of B. longum, B. animalis, or B. bifidum. Therefore, proper modification of

481 plasmid DNA can help to bypass the restriction barriers and favour the acquisition of

482 foreign recombinant DNA by bifidobacteria. This assumption has been verified by a

483 recent study, in which site-directed mutagenesis and in vitro methylation were applied

484 to remove or modify restriction sites from a vector pYBamy59 before

485 electrotransformation into B. longum MG1 (Kim et al., 2010). In this study, sequence

486 analysis of pYBamy59 fragments originated by incubation of recombinant DNA with

487 cell extracts of MG1, revealed the presence of a SacII-like endonuclease activity,

488 recognizing the palindromic sequence 5'-CCGCGG-3'. When pYBamy59 from E. coli

489 was methylated in vitro by $\mathrm{CpG}$ or GpC methyltransferases, or when SacII sites were

490 removed from pYBamy59 through site-directed mutagenesis, the transformation

491 efficiency showed 8- to 15-fold increment as compared to the original plasmid (Kim et

492 al., 2010).

493 Another strategy to modify recombinant DNA before introduction into

494 bifidobacterial cells was recently adopted in two independent studies (Yasui et al.,

495 2009; O’Connell-Motherway et al., 2009), with the aim to boost the transformation

496 efficiency of B. adolescentis ATCC 15703 and B. breve UCC2003, respectively. In this

497 strategy, a shuttle vector was pre-methylated in Escherichia coli cells carrying the

498 genes encoding the DNA modification enzymes of the target Bifidobacterium before

499 electroporation (Fig. 3). In fact, Yasui and coworkers (2009) developed a system called 
"Plasmid Artificial Modification" (PAM) and demonstrated its efficacy for the target

501 host B. adolescentis ATCC 15703, a strain that could be transformed only at an

502 extremely low level. In the ATCC 15703 genome, they identified two Type II DNA

503 methyltransferase genes, BAD_1233 and BAD_1383, which they cloned in E. coli

504 TOP10 (Invitrogen) by means of a low copy number vector, obtaining the so-called

505 "PAM host." The E. coli TOP10 laboratory strain was shown to be the most suitable

506 because it lacks the Type IV restriction enzymes $m r r$ and $m c r B C$ (which degrade DNA

507 methylated by the R-M system of other bacteria) and the methylases $d a m$, $d c m$, and

$508 h s d M S$ (which can make the DNA sensitive to possible Type IV restriction systems).

509 Subsequently, an E. coli-Bifidobacterium shuttle vector, based on the pTB6 B. longum

510 replicon (Tanaka et al., 2005), was introduced into the PAM host. Transformation

511 efficiency improved considerably when B. adolescentis was electroporated with the

512 shuttle vector DNA isolated from the PAM host, jumping from $1-3 \times 10^{0}$ to $10^{5}$

$513 \mathrm{CFU} / \mu \mathrm{g}$. This confirms that the shuttle vector was methylated by the modification

514 enzyme encoded by the PAM plasmid in the E. coli host and consequently protected

515 against restriction by B. adolescentis (Fig. 3).

516 The same approach was adopted by O'Connell-Motherway et al. (2009) with $B$.

517 breve UCC2003 as the target host. In the annotated genome of this strain, they found

518 three different R-M gene clusters, including the methylase genes $b b r I M$, bbrIIM and

519 bbrIIIM. The role of these modification genes in the acquisition of exogenous DNA by

520 B. breve was studied in transformation experiments with pAM5-derived vectors (based

521 on the pBC1 replicon from B. catenulatum; Álvarez-Martín et al., 2007b). The authors

522 observed a 1000-, 10-, and 5-fold higher transformation frequency for pAM5 DNA

523 isolated from E. coli expressing M.BbrIII, M.BbrII, and M.BbrI, respectively, which 
524 indicates that, although differently, all three DNA methylation systems affected the 525 transformation efficiency.

526 The above studies demonstrated the usefulness of artificially modified DNA by

527 means of the host methylases to increase the electroporation efficiency. Genome

528 analyses and experimental data, however, have shown that Bifidobacterium strains

529 harbour a very diverse range of R-M activities, even within the same species

530 (O'Connell-Motherway et al., 2009). Therefore, this strategy is at least partly limited to

531 the strains whose whole-genome sequence is known. To overcome this problem,

532 O'Connell-Motherway et al. (2009) proposed the possibility of methylating exogenous

533 DNA isolated from E. coli in vitro, through incubation of the DNA with cell extracts of

534 the target host in the presence of S-adenosylmethionine. However, experimental data

535 of the practicability and effectiveness of this strategy are not yet available.

\subsection{Conjugation in bifidobacteria}

538 The R-M barriers of a bacterial strain can also be bypassed by introducing foreign

539 DNA through conjugation. Conjugation may occur when cis (oriT) and trans (transfer

540 proteins, Mob and Tra) elements found in mobilizing plasmids are recognized by

541 cellular components, which can be supplied by the host cell. Putative Mob and Tra

542 protein coding genes and characteristic cis elements have been found in several

543 bifidobacterial plasmids (O'Riordan and Fitzgeralds, 1999; Corneau et al., 2004; Gibbs

544 et al., 2006; Shkoporov et al., 2008a; Table 1), suggesting their mobilization potential.

545 Nevertheless, up to now, no DNA transfer system based on conjugation is available for

546 members of the genus Bifidobacterium, and no conjugation events have been

547 irrefutably demonstrated. The only documented systematic attempt to achieve

548 conjugation in bifidobacteria was made by Shkoporov and collaborators (2008a), who 
exploited the mobilization functions of three different Bifidobacterium plasmids to

550 develop genetic tools based on the well characterized intergeneric conjugative element

551 RP4 (IncP $\alpha)$ (Simon et al., 1983) to transfer DNA into B. pseudocatenulatum. They

552 produced antibiotic-resistant clones that, though PCR-positive, did not contain the

553 expected plasmid DNA. Consequently, development of effective conjugation systems

554 for bifidobacteria, albeit potentially useful, remains in its infancy.

\subsection{Expression of heterologous genes among bifidobacteria}

The development of heterologous expression and secretion systems is strategically important for studying the properties of Bifidobacterium because of strain

559 improvement and delivery into the human digestive tract of useful gene products such

560 as vaccines or anticarcinogenic polypeptides.

$561 \quad$ Heterologous genes from a diverse group of organisms have been expressed in

562 bifidobacteria under the control of either heterologous or homologous promoters

563 (Table 3). The current list includes genes and promoters mainly from Gram-negative

564 and Gram-positive bacteria, but with exceptions, as the luciferase gene from

565 Pyrophorus plagiophthalamus (Guglielmetti et al., 2008a) and several human genes

566 (Xu et al., 2007). In addition to the genes reported in Table 3, several antibiotic

567 resistance genes, used in preparing cloning and expression vectors, have been shown to

568 be functional in bifidobacteria even under the control of their own regulatory elements.

569 They include, for instance, the chloramphenicol acetyl transferase (cat) of the plasmid

570 pC194, the erythromycin resistance gene of pE194 from Staphylococcus aureus, and

571 the spectinomycin resistence gene from Enterococcus faecalis. In contrast, the

572 thiostrepton resistance gene from Streptomyces is not functional in bifidobacteria

573 (Rossi et al., 1998, Guglielmetti et al., 2007b). Similarly, the genes coding for 
575 sp. cholesterol oxidase, are stably maintained in the bifidobacterial host, but under the 576 control of their own promoters they are not expressed (Rossi et al., 1998).

577 With respect to protein expression in bifidobacteria, excretion and secretion

578 processes should be studied to develop export systems for expressed heterologous

579 proteins or enzymes. In this context, MacConaill and collaborators (2003) investigated

580 protein export in B. breve UCC2003 by means of the export-specific vector pFUN,

581 based on the use of the staphylococcal nuclease (Nuc) as a reporter enzyme (Poquet et

582 al., 1998). Due to the removal of its native signal peptide, the Nuc reporter protein is

583 translocation-competent but unable to direct its own secretion. In this study,

584 translational fusions were constructed with a nuc gene and the export signal provided

585 by inserted $B$. breve chromosomal DNA fragments. By this strategy, seven signal

586 peptides have been identified for B. breve UCC2003 (MacConaill et al., 2003).

587 Recently, a secretion system has also been developed based on the $\alpha$-amylase

588 expression and secretion signals isolated from B. adolescentis INT57 (Park et al.,

589 2005b; Rhim et al., 2006). Park and collaborators constructed a secretion vector,

590 pBESAF2, containing the promoter and the signal peptide of the $\alpha$-amylase gene

$591 a m y B$. The gene encoding an intracellular phytase from $E$. coli was introduced in this

592 vector and transcriptionally fused to the signal sequence and finally introduced by

593 electroporation in B. longum MG1. The authors demonstrated that, by using this

594 system, phytase enzyme was successfully expressed and secreted by B. longum into the

595 culture broth. Furthermore, this system was employed for expression and secretion by

596 B. longum MB1 of the bacteriocin pediocin PA-1 from Pediococcus acidilactici K10

597 (Moon et al., 2005). 
Analogously, Deng and collaborators (2009) selected through computational

599 analysis the signal peptide sequence from the endo-1,5- $\alpha$-L-arabinosidase gene of $B$.

600 longum NCC2705, by which they obtain expression and secretion of the human

601 interferon- $\alpha 2 b$ protein (IFN- $\alpha 2 b$ ) in B. longum ATCC 15707. This study showed that

$60265 \%$ of the total IFN- $\alpha 2 b$ was secreted from $B$. longum in the presence of the

603 arabinosidase signal peptide, while only $15 \%$ of the protein was secreted without the

604 signal peptide. Surprisingly, this experimentation was carried out without a

605 conventional E. coli-Bifidobacterium shuttle plasmid, but by means of the commercial

606 pBR322-based vector pBAD-gIIIA (Invitrogen), in which expression of the

607 recombinant protein is arabinose-inducible by the presence of the promoter of the

608 arabinose operon from E. coli. The maximal level of induction was obtained after

609 addition of $0.2 \%$ arabinose (Deng et al., 2009). Finally, Long et al. (2010)

610 demonstrated that the exo-xylanase $(\mathrm{XynF})$ signal peptide sequence from $B$. longum

611 was suitable to guide secretion of the mature peptide of the human gut hormone

612 oxyntomodulin.

613 Information on regulated promoters, inducers, and repressors is extremely limited

614 in bifidobacteria. Additional efforts are, therefore, needed to identify strong, weak, and

615 regulated promoters for controlled gene expression in bifidobacteria under different

616 environmental conditions. However, current knowledge on the expression of

617 heterologous genes in Bifidobacterium has enabled development of reporter gene and

618 drug delivery systems as potentially promising tools for future research and

619 pharmaceutical applications.

620

$621 \quad$ 5.3.1. Reporter gene systems 
Some reporter gene systems have already been developed and shown useful for several applications. To study promoter strength and regulation analysis or to identify

624 genomic fragments containing active promoters, Klijn and co-workers (2006)

625 developed the reporter vector pMDY23 based on the Escherichia coli $\beta$-glucuronidase gene gusA and the small cryptic B. longum plasmid pNCC293. After introducing the vector in B. longum NCC2705, they demonstrated the suitability of pMDY23 as a reporter plasmid for promoter study by analyzing the promoter activity of three DNA fragments (Klijn et al., 2006; Table 3).

More recently, two studies showed the application of bioluminescence reporter genes in Bifidobacterium spp. (Guglielmetti et al., 2008a; Cronin et al., 2008).

Guglielmetti and collaborators transformed by electroporation the human intestinal strain B. longum subsp. longum NCC2705 with a vector (pGBL8b) containing the 634 insect luciferase gene lucGR from a click beetle (Pyrophorus plagiophthalamus). The 635 same vector, however, was incapable of transforming B. animalis subsp. lactis BB12 636 and B. bifidum MIMBb75 (Guglielmetti et al., 2008a; S. Guglielmetti, unpublished).

637 The resulting bioluminescent $B$. longum was used to analyze variations in intracellular 638 ATP concentration at acidic $\mathrm{pH}$ in the presence of different sugars, a technique proving 639 to be a valuable tool for the rapid and sensitive study of the physiological state of 640 bacterial cells under different environmental conditions. Nonetheless, the need to add 641 exogenous D-luciferin as a substrate in this reporter system limits considerably its in 642 vivo application.

643 The bacterial luciferase system (coded by the luxABCDE operon) is generally less 644 sensitive than insect luciferases, yet bacterial luciferase requires as substrate a long645 chain fatty aldehyde, which is intracellularly synthesized by a fatty acid reductase 646 complex encoded by $\operatorname{lux} C D E$. Therefore, the intracellular expression of the lux operon 
647 circumvents the disadvantage of exogenous addition of luciferin and is thus more

648 suitable for in vivo applications. Cronin et al. (2008) adopted the lux operon to develop

649 the non-invasive luciferase reporter vector pLuxMC1, which was introduced in $B$.

650 breve UCC2003. Once mice were orally inoculated with bioluminescent $B$. breve, the

651 reporter system allowed a real-time tracking of the colonisation and persistence of this 652 probiotic strain in vivo.

653

654

5.3.2. Drug delivery systems

655

Due to their safety and ability to colonize specific areas of the human

656 gastrointestinal tract, bifidobacteria may turn out to be optimal vectors for in situ delivery of biologically active substances. Of particular interest is the fact that certain anaerobic bacteria, including species of Clostridium and Bifidobacterium, can selectively germinate and grow in the hypoxic regions of solid tumors (Malmgren and

660 Flanigan, 1955; Kimura et al., 1980; Yazawa et al., 2000; Yazawa et al., 2001), such as 661 those of most primary breast and uterine cervix cancers. This fact was exploited by the 662 Japanese research team of Prof. Fujimori, who developed a strategy called “Bifidobacterial Selective Targeting” (BEST) (Fujimori, 2006). The Fujimori team's

664 BEST therapy involved the strain B. longum 105-A, which was genetically engineered 665 via electro-transformation with pBLES100-S-eCD, a plasmid based on the shuttle 666 vector pBLES100 (Matsumura et al., 1997) and comprising the cytosine deaminase 667 gene (CD) under the hup gene promoter of B. longum (Nakamura et al., 2002; Table 3), 668 which codes for a histone-like DNA-compacting protein. The CD enzyme converts the 669 non-toxic prodrug 5-fluorocytosine (5-FC) to chemotherapeutic 5-fluorouracil (5-FU), 670 which is systemically administrated to treat solid tumors. In conventional therapy, its 671 clinical effectiveness is very limited by its high systemic toxicity, particularly toward 
672 the bone marrow. Fujimori's studies demonstrated that recombinant B. longum

673 selectively produced CD in mammary tumor tissues in rats, and that CD could convert

674 5-FC into 5-FU in vivo both after intratumoral injection and also by systemic

675 administration (Sasaki et al., 2006). Furthermore, no adverse effects were observed in

676 animal models during the use of B. longum as a gene delivery vector (Sasaki et al.,

677 2006), a finding supporting the potential effectiveness of this novel approach for

678 cancer gene therapy in humans. More recently, it was developed an improved version

679 of pBLES100-S-eCD, able to display 10-fold increased CD activity in B. longum

680 (Hamaji et al., 2007). They demonstrated that the BEST approach works well even

681 with a different bifidobacterial species, such as B. breve I-53-8w (Hidaka et al., 2007).

682 Bifidobacteria have been used as a gene delivery vehicle of $\mathrm{CD}$ also by Chinese

683 researchers, who expressed the $\mathrm{CD}$ gene in $B$. longum subsp. infantis by means of the

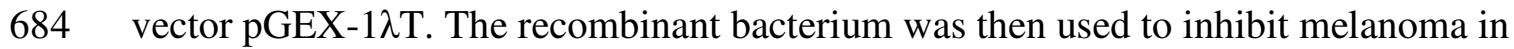

685 mice (Yi et al., 2005). As for the Invitrogen vector pBAD-gIIIA mentioned above, the

686 functionality of the vector pGEX-1 $1 \lambda \mathrm{T}$ is surprising, because it carries no bifidobacterial

687 replicon but only the pBR322 ori region. Moreover, Yi and collaborators claimed that

688 the recombinant bifidobacteria were selected with ampicillin through the $\beta$-lactamase

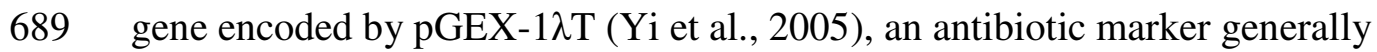

690 considered not to be active in Gram-positives. The same research team used this

691 approach to clone the Herpes simplex virus-thymidine kinase (HSV-TK) in B. longum

692 subsp. infantis. In this system, the thymidine kinase expressed specifically in tumor

693 tissues by bacterial cells, can convert the non-toxic precursor ganciclovir into the

694 ganciclovir-3-phosphate, a toxic substance that kills the tumoral cells. The efficacy of

695 this gene therapy system was demonstrated in vivo in a rat model of bladder cancer.

696 After tail vein injection of $4.4 \times 10^{9}$ recombinant Bifidobacterium cells with a 
697 concomitant daily intraperitoneal injection of Ganciclovir, on the $15^{\text {th }}$ day after the

698 beginning of the treatment, rat bladder tumor growth was inhibited (Tang et al., 2009).

699 The BEST strategy was adopted also by Prof. Xu's research team, who employed

700 B. adolescentis and B. longum as gene delivery vectors to transport the anti-angiogenic

701 factor endostatin into a hypoxic solid liver tumor in mice (Li et al., 2003, Fu et al.,

702 2005, Xu et al., 2007). Originally, they claimed that expression of the human liver

703 endostatin gene was achieved in Bifidobacterium spp. by means of the expression

704 plasmid pBV220. The vector pBV220 (Zhang et al. 1990) is a derivative of pBR322

705 and contains $\mathrm{P}_{\mathrm{R}} \mathrm{P}_{\mathrm{L}}$ promotors of the $\lambda$ bacteriophage, the $c$ I857ts gene encoding the

706 temperature-sensitive $\lambda$ repressor, and two strong transcriptional terminators

707 (rrnBT1T2) of E. coli. This vector only contains the origin of replication of pBR322

708 and a unique antibiotic selection for ampicillin ( $\beta$-lactamase gene). As for the vectors

709 pBAD-gIIIA and pGEX-1 $\lambda \mathrm{T}$, it is therefore once again unexpected that pBV220 was

710 found functional in bifidobacteria. The same authors reported, however, that this

711 construct was highly unstable in B. longum (Xu et al., 2007). Therefore, it was

712 modified by introducing the pMB1 Bifidobacterium replicon (Rossi et al., 1996) and a

713 chloramphenicol resistance gene. The resulting vector, called pBV22210, was much

714 more stably maintained in B. longum than pBV220 (Xu et al., 2007). Very recently, the

715 plasmid pBV22210 has also been used in B. longum as an expression vehicle of the

716 extracellular domain of TNF-related apoptosis-inducing ligand (TRAIL). The resulting

717 recombinant strain was shown to have a specific antitumor effect on mouse

718 osteosarcoma (Hu et al., 2009). In a following study, vector pBV22210 was also used

719 to express in B. longum the granulocyte colony-stimulating factor (G-CSF), a molecule

720 frequently used as a coadjuvant agent in tumor chemotherapy. When B. longum-

721 pBV22210-GCSF was applied to treat H22 and S180 sarcoma-bearing mice, it was 
observed an effective antagonistic effect on bone marrow inhibited by

723 cyclophosphamide and an over 65\% inhibition of tumor growth (Zhu et al., 2009).

724 Finally, the BEST strategy was adopted by Hou and colleagues (2006), who observed a

725 significant inhibition of the growth of solid tumors in a knock-out mice lacking the

726 phosphatase and tensin (PTEN) homolog with a genetically engineered B. longum, transformed with a pMB1-derived vector expressing the PTEN tumor suppressor gene under the hup gene promoter from B. longum.

Other gene delivery systems have recently been developed in bifidobacteria. For instance, it was developed a vaccine delivery system based on B. animalis ATCC 27536, genetically modified through transformation with the vector pBLES100, in which they cloned the flagellin gene fliC of Salmonella Typhimurium ATCC 14028 under the B. longum hup gene promoter (Takata et al., 2006). Significantly higher

734 levels of flagellin-specific IgA in the serum and stools of mice treated by oral

735 administration of this recombinant $B$. animalis than in those treated with parental $B$.

736 animalis, were detected (Takata et al., 2006). In a recent work, these authors studied

737 the potential effectiveness of genetically modified bifidobacteria as oral vaccines by

738 protecting mice from a lethal challenge with Salmonella in a typhoid fever model

739 (Yamamoto et al., 2010).

740 Another pioneering application of bifidobacteria as drug delivery system was that 741 of Long and collaborators (2010), who developed engineered bifidobacteria as oral 742 carriers of oxyntomodulin, a gut hormone that is used to reduce food intake and body 743 weight through intravenous administration. Interestingly, the results of this study 744 showed that oxyntomodulin-transformed B. longum reduced food intake, body weight 745 and decreases blood lipid in overweight mice. The benefits were identical to those 
obtained by oral administration of Orlistat, a gastrointestinal lipase inhibitor drug employed in obesity therapy (Long et al., 2010).

As suggested by recent studies, bifidobacteria may also be used for the in situ delivery of human cytokines. The ani-inflammatory interleukin (IL)-10 has been expressed in its mature form by B. longum ATCC 15707 (Reyes Escogido et al., 2007; Table 3) and B. breve UCC2003 (Khokhlova et al., 2010). In the latter study, the gene coding for the mature form of human IL-10 was translationally fused to previously described Bifidobacterium signal peptides and placed under the control of bifidobacterial constitutive promoters. Specifically, a pB80 replicon-based shuttle vector carrying active promoter and terminator regions of B. longum gene hup, was used to clone gene IL-10, which was fused with the signal peptide regions of genes sec2, $a p u B$ or $a m y B$, coding for $B$. breve secreted protein and extracellular amylopullulanase and B. adolescentis secreted alfa-amylase, respectively. Sec2 signal peptide was also placed under the control of constitutive promoter/terminator regions from B. longum gene gap, coding for enzyme glyceraldehyde-3-phosphate dehydrogenase. Interestengly, RT-qPCR experiments demonstrated that the expression level of IL-10 driven by gap promoter was higher than that under the control of hup promoter. Moreover, substitution of the Sec2 signal peptide-coding region with the signal sequence from $a m y B$ gene resulted in an intensely elevated level of IL-10 mRNA (Khokhlova et al., 2010).

\subsection{Knock-out of bifidobacterial genes}

The prime method for studying the function of a gene and its impact on the overall cellular physiology and morphology consists in removing or disrupting the gene from its host (gene knock-out). This is generally accomplished by means of modification 
systems based on homologous recombination. A low occurrence of homologous recombination has been reported in bifidobacteria, which agrees well with the absence of the major prokaryotic DNA recombination pathway encoded by recBCD in the genome of some strains, such as B. longum NCC2705 (Schell et al., 2002). As discussed previously, bifidobacteria display relatively low transformation efficiency. Evidently, the recombination frequency in Bifidobacterium is thus generally lower than that of transformation, limiting effective chromosomal integration of DNA. For these reasons, successful homologous recombination in bifidobacteria has only recently been reported.

$$
\text { In 2008, it was published successful knockouts of B. breve UCC2003 genes by }
$$
single-crossover recombination, employing two different strategies (O’ConnelMotherway et al., 2008). First, O'Connel-Motherway and co-workers adopted a double-vector integration strategy to disrupt the amylopullulanase gene $a p u B$. The first vector contained the origin of replication but lacked the rep gene coding for its replication protein (Ori+/Rep- vector). The second vector, bearing a different antibiotic resistance, was a derivative of the lactococcal temperature-sensitive plasmid pVE6007 and harboured the rep gene of the former plasmid (Rep+ vector). An internal $1 \mathrm{~kb}$ DNA region of the $a p u B$ gene was cloned in the Ori+/Rep- plasmid, and both vectors (Ori+/Rep- and Rep+) were then introduced in B. breve UCC2003 under double antibiotic selection. In such recombinant cells, the Ori+/Rep- plasmid could replicate only in the presence of the other vector, which supplied the Rep protein in trans. Once the recombinant $B$. breve was cultivated at a high temperature $\left(42{ }^{\circ} \mathrm{C}\right)$ and with selection only for the Ori+/Rep- vector, the Rep+ plasmid was lost from $B$. breve cells due to its temperature sensitivity and segregational instability. Accordingly, under selective conditions, the Ori+/Rep- plasmid has to integrate into the chromosome. 
Thanks to this approach, the authors found by replica plaiting some $B$. breve apuB

797 disruption isolates, which exhibited the expected phenotype and in which they verified

798 plasmid integration by PCR and Southern hybridization. However, O'Connell-

799 Motherway and collaborators emphasized that this system is very tedious, time-

800 consuming, and unreliable (O'Connell-Motherway et al., 2008).

801 In a later publication, the same researchers described insertional mutagenesis of

802 the $a p u B$ gene and the endogalactanase gene (galA) of B. breve UCC2003 by means of

803 plasmid methylation (O'Connell-Motherway et al., 2009). This strategy produced gene

804 disruptions by single-crossover chromosomal integration of non-replicative plasmids

805 containing internal fragments of 476 and $744 \mathrm{bp}$ of the galA gene, and a $939 \mathrm{bp}$

806 internal fragment of the $а р и B$ gene. These three plasmids were first introduced into an

807 E. coli host harbouring two B. breve UCC2003 methylase genes (bbrIIM and bbrIIIM).

808 The resulting methylated plasmids were then introduced into B. breve UCC2003 by

809 electroporation. Antibiotic-resistant transformants were isolated for all methylated

810 vectors at a frequency of up to 50 per $\mu \mathrm{g}$ of transformed DNA. No transformants were

811 obtained when unmethylated constructs were introduced into strain UCC2003. The

812 expected integration in the chromosome was finally verified by genetic and phenotypic

813 analyses. These results by O'Connell-Motherway et al. (2009) showed that methylation

814 of the non-replicating plasmid by B. breve UCC2003 methylases increased

815 transformation efficiency to a level sufficiently high to allow site-specific homologous

816 recombination to occur. This strategy has allowed the dissection of many genes from

817 the UCC2003 strain, including gene components of clusters involved in utilization of

818 ribose (Pokusaeva et al., 2010), insoluble cellulose (cellodextrin) (Pokusaeva et al.,

819 2011), and galactans (O’Connell Motherway et al., 2011b). 
Also recently, Arigoni and Delley (2008) patented a gene deletion method in

821 Bifidobacterium by two consecutive events of homologous recombination. The authors

822 reported deletion of the tetracycline resistance gene tet $(\mathrm{W})$ from $B$. animalis subsp.

823 lactis NCC2818 (commercially known as strain BB12). Their method comprised the

824 following steps. DNA fragments of approximately $3 \mathrm{~kb}$ flanking the $\operatorname{tet}(\mathrm{W})$ gene were

825 amplified and joined via the start and stop codon of $\operatorname{tet}(\mathrm{W})$. The resultant $6 \mathrm{~kb}$ DNA

826 fragment was cloned in pJL74 (LeDeaux and Grossman, 1995), a spectinomycin

827 resistance vector unable to replicate in bifidobacteria; the resulting plasmid was

828 introduced in B. animalis subsp. lactis $\mathrm{NCC} 2818$. Spectinomycin-resistant $\left(\mathrm{spec}^{\mathrm{R}}\right)$

829 colonies were shown to harbour the plasmid integrated into the B. animalis

830 chromosome via a single cross-over event. $\mathrm{Spec}^{\mathrm{R}}$ transformants were then cultivated

831 for about 100 generations without antibiotic selection to promote loss of the plasmid.

832 Spectinomycin-sensitive $\left(\mathrm{spec}^{\mathrm{S}}\right)$ colonies were then selected by replica plating on MRS

833 agar with or without added spectinomycin. Twenty-one percent of the tested colonies

834 were $\operatorname{spec}^{\mathrm{S}}$, indicating that a second cross-over event had occurred, which resulted in

835 excision of the vector from the chromosome. Finally, out of the $135 \mathrm{Spec}^{\mathrm{S}}$ colonies

836 tested by PCR, two had received the deletion of the tet $(\mathrm{W})$ gene. The same strategy

837 was used to delete a protease inhibitor (serpin-like) gene (BL0108) from B. longum

838 NCC2705 with two positive recombinant colonies out of 12 colonies tested in the final

839 PCR screening. This study showed for the first time an in frame deletion of a specific

840 entire gene in Bifidobacterium, achieved by targeted double cross-over recombination.

841 The application of plasmid artificial modification (PAM) system to this knock-out

842 strategy is likely to be a powerful tool for future gene deletion/replacement in

843 Bifidobacterium. 


\section{Concluding remarks and future perspectives}

A bunch of bifidobacterial plasmids have already been sequenced and analysed

847 from several Bifidobacterium species, which has allowed the development of some

848 rudimentary cloning and expression vectors. However, there is still a lack of

849 knowledge about the basic biology of plasmids for them to be used with confidence.

850 Dissection of translated and untranslated sequences will aid to define the functionality

851 of the different plasmid elements found. This will help the designing of high-copy and

852 low-copy number vectors for the fine-tuning expression of homologous and

853 heterologous genes, while increasing stability of the constructs. Polishing and refining

854 currently-in-use vectors and broaden their positive selection will also be useful for

855 many molecular studies, as well as for the development of compatible systems

856 allowing introduction of two vectors in a single cell. The construction of food-grade

857 vectors, i.e. having no foreign DNA and free of antibiotic resistance makers, would

858 further facilitate the future industrial use of genetically modified bifidobacteria.

859 Nonetheless, at present, the lack of efficient gene knock-out protocols that can be

860 efficiently applied to virtually all bifidobacterial species is the main limitation to the

861 study of physiological and probiotic properties of bifidobacteria. Gene knock-out is, in

862 fact, the golden procedure to unambiguously understand the role of a specific coding

863 sequence. A few studies (Arigoni and Delley, 2008; O'Connell-Motherway et al.,

864 2008) demonstrated that standard knock-out procedures, based on homologous

865 recombination, can be practicable in bifidobacteria, provided the frequency of

866 transformation is sufficiently high. A suitable transformation rate could be potentially

867 reached by combining different expedients, which can be deduced from the

868 investigations presented in this review article, such as the use of strict anaerobic

869 conditions during preparation of competent cells and electroporation (to increase 
870 viability) and the employment of any possible strategy useful to overcome

871 bifidobacterial restriction barriers. To this aim, it appears promising the set-up of

872 protocols for the in vitro methylation of recombinant DNA before transformation, in

873 spite of the improved transformation efficiency obtained by the laborious method of 874 the PAM strategy.

875 Nowadays, the European regulation concerning health claims on product labels

876 (EC regulation 1924/2006) ratifies the need for an approval from the European Food

877 Safety Authority (EFSA) for the efficacy of any specific probiotic product. As a

878 consequence, industrial producers are demanding new efficient research instruments

879 that can permit effective verification and demonstration of the health-promoting

880 properties associated to probiotic microorganisms, such as bifidobacteria. In addition to

881 technological reasons, such rapidly growing whole genome sequence data, the

882 increasing interest of food and pharmaceutical industries on probiotics is boosting the

883 research on bifidobacteria. It is, therefore, expected that in the next few years further

884 steps will be done in the genetic modification of these organisms.

885

886

\section{Acknowlegments}

887 Work at the author's laboratory has been supported by projects from the Spanish

888 Ministry of Economy and Competitiveness (AGL2011-24300) and FICYT (Ref. IB08-

889 005) to B.M.

890

$891 \quad$ Disclosure

892 This manuscript is an extended and updated version of the manuscript "Mobile

893 genetic elements, cloning vectors and genetic manipulation of bifidobacteria", 
894 published as a chapter in the book "Bifidobacteria. Genomics and Applied Aspects",

895 by B. Mayo and D. Van Sinderen (eds.), Caister Academic Press, Norfolk, UK.

896

897

\section{References}

898 Álvarez-Martín P, O’Connell-Motherway M, van Sinderen D, Mayo B. (2007a).

899 Functional analysis of the $\mathrm{pBC} 1$ replicon from Bifidobacterium catenulatum L48.

$900 \quad$ Appl Microbiol Biotechnol, 76, 1395-1402.

901 Álvarez-Martín P, Flórez AB, Mayo B. (2007b). Screening for plasmids among human

902 bifidobacteria species: Sequencing and analysis of pBC1 from Bifidobacterium

903 catenulatum L48. Plasmid, 57, 165-74.

904 Álvarez-Martín P, Flórez AB, Margolles A, del Solar G, Mayo B. (2008). Improved

905 cloning vectors for bifidobacteria, based on the Bifidobacterium catenulatum pBC1

906 replicon. Appl Environ Microbiol, 74, 4656-65.

907 Ammor MS, Flórez AB, Álvarez-Martín P, Margolles A, Mayo B. (2008). Analysis of

908 tetracycline resistance $\operatorname{tet}(\mathrm{W})$ genes and their flanking sequences in intestinal

909 Bifidobacterium species. J Antimicrob Chemother, 62, 688-93.

910 Argnani A, Leer RJ, van Luijk N, Pouwels PH. (1996). A convenient and reproducible

911 method to genetically transform bacteria of the genus Bifidobacterium. Microbiol,

$912 \quad 142,109-14$.

913 Arigoni F, Delley M. (2008). Genetic remodelling in Bifidobacterium. International

914 Patent WO 2008/019886 A1.

915 Barrangou R, Briczinski EP, Traeger LL, Loquasto JR, Richards M, Horvath P, Coûté-

916 Monvoisin AC, Leyer G, Rendulic S, Steele JL, Broadbent JR, Oberg T, Dudley EG,

917 Schuster S, Romero DA, Roberts RF. (2009). Comparison of the complete genome 
$919 \quad$ Bacteriol, 191, 4144-51.

920 Brown DP, Idler KB, Katz L. (1990). Characterization of the genetic elements required

921 for site-specific integration of plasmid pSE211 in Saccharopolyspora erythraea. J

922 Bacteriol, 172, 1877-88.

923 Campbell AM. (1992). Chromosomal insertion sites for phages and plasmids. J

924 Bacteriol, 174, 7495-9.

925 Canchaya C, Proux C, Fournous G, Bruttin A, Brussow H. (2003). Prophage genomics.

926 Microbiol Mol Biol Rev, 67, 238-76.

927 Claesson MJ, Cusack S, O'Sullivan O, Greene-Diniz R, de Weerd H, Flannery E,

928 Marchesi JR, Falush D, Dinan T, Fitzgerald G, Stanton C, van Sinderen D, O'Connor

929 M, Harnedy N, O'Connor K, Henry C, O'Mahony D, Fitzgerald AP, Shanahan F,

930 Twomey C, Hill C, Ross RP, O'Toole PW. Composition, variability, and temporal

931 stability of the intestinal microbiota of the elderly. Proc Natl Acad Sci U S A, 108,

932 Suppl 1, 4586-91.

933 Combes P, Till R, Bee S, Smith MCM. (2002). The Streptomyces genome contains

934 multiple pseudo-attB sites for the phage C31-encoded site-specific recombination 935 system. J Bacteriol, 184, 5746-52.

936 Corneau N, Emond E, LaPointe G. (2004). Molecular characterization of three

937 plasmids from Bifidobacterium longum. Plasmid, 51, 87-100.

938 Cronin M, Knobel M, O’Connell-Motherway M, Fitzgerald GF, van Sinderen D.

939 (2007). Molecular dissection of a bifidobacterial replicon. Appl Environ Microbiol, $940 \quad 73,7858-66$. 
941 Cronin M, Sleator RD, Hill C, Fitzgerald GF, van Sinderen D. (2008). Development of

942 a luciferase-based reporter system to monitor Bifidobacterium breve UCC2003

943 persistence in mice. BMC Microbiol, 8,161.

944 del Solar G, Giraldo R, Ruiz-Echevarría MJ, Espinosa M, Díaz-Orejas R. (1998).

945 Replication and control of circular bacterial plasmids. Microbiol Mol Biol Rev, 62,

$946 \quad 434-64$.

947 Deng Q, Zeng W, Yu Z. (2009). Signal peptide of arabinosidase enhances secretion of

948 interferon-alpha2b protein by Bifidobacteria longum. Arch Microbiol, 191, 681-6.

949 Fanaro S, Chierici R, Guerrini P, Vigi V. (2003). Intestinal microflora in early infancy:

950 composition and development. Acta Paediatr Suppl, 91, 48-55.

951 Fanning S, Hall LJ, Cronin M, Zomer A, MacSharry J, Goulding D, Motherway MO,

952 Shanahan F, Nally K, Dougan G, van Sinderen D. (2012). Bifidobacterial surface-

953 exopolysaccharide facilitates commensal-host interaction through immune

954 modulation and pathogen protection. Proc Natl Acad Sci U S A, 109, 2108-13.

955 Fischer W. (1987). Analysis of the lipoteichoic acid-like macroamphiphile from

956 Bifidobacteriuim bifidum subspecies pennsylvanium by one- and two-dimensional

957 1H- and 13C-NMR spectroscopy. Eur J Biochem, 165, 647-52.

958 Foroni E, Serafini F, Amidani D, Turroni F, He F, Bottacini F, O'Connell Motherway

959 M, Viappiani A, Zhang Z, Rivetti C, van Sinderen D, Ventura M. (2011). Genetic

960 analysis and morphological identification of pilus-like structures in members of the

961 genus Bifidobacterium. Microb Cell Fact, 10, Suppl 1,S16.

962 Frost LS, Leplae R, Summers AO, Toussaint A. (2005). Mobile genetic elements: the

963 agents of open source evolution. Nat Rev Microbiol, 3, 722-32. 
964 Fu GF, Li X, Hou YY, Fan YR, Liu WH, Xu GX. (2005). Bifidobacterium longum as

965 an oral delivery system of endostatin for gene therapy on solid liver cancer. Cancer

966 Gene Ther, 12, 133-40.

967 Fujimori M. (2006). Genetically engineered Bifidobacterium as a drug delivery system

968 for systemic therapy of metastatic breast cancer patients. Breast Cancer, 13, 27-31.

969 Fukiya S, Sugiyama T, Kano Y, Yokota A. (2010). Characterization of an insertion

970 sequence-like element, ISBlo15, identified in a size-increased cryptic plasmid

971 pBK283 in Bifidobacterium longum BK28. J Biosci Bioeng, 110, 141-6.

972 Garrigues C, Johansen E, Pedersen MB. (2010). Complete genome sequence of

973 Bifidobacterium animalis subsp. lactis BB-12, a widely consumed probiotic strain. J

974 Bacteriol, 192, 2467-8.

975 Gibbs MJ, Smeianov VV, Steele JL, Upcroft P, Efimov BA. (2006). Two families of

976 rep-like genes that probably originated by interspecies recombination are represented

977 in viral, plasmid, bacterial, and parasitic protozoan genomes. Mol Biol Evol, 23,

$978 \quad 1097-100$.

979 González Vara A, Rossi M, Altomare L, Eikmanns B, Matteuzzi D. (2003). Stability of 980 recombinant plasmids on the continuous culture of Bifidobacterium animalis ATCC 981 27536. Biotechnol Bioengineering, 84, 145-50.

982 Guglielmetti S, Mora D, Parini C. (2007a) Small rolling circle plasmids in Bacillus

983 subtilis and related species: organization, distribution, and their possible role in host 984 physiology. Plasmid, 57, 245-64.

985 Guglielmetti S, Karp M, Mora D, Tamagnini I, Parini C. (2007b). Molecular 986 characterization of Bifidobacterium longum biovar longum NAL8 plasmids and 987 construction of a novel replicon screening system. Appl Microbiol Biotechnol, 74, 988 1053-61. 
989 Guglielmetti S, Ciranna A, Mora D, Parini C, Karp M. (2008a). Construction,

990 characterization and exemplificative application of bioluminescent Bifidobacterium

991 longum biovar longum. Int J Food Microbiol, 124, 285-90.

992 Guglielmetti S, Tamagnini I, Mora D, Minuzzo M, Scarafoni A, Arioli S, Hellman J,

993 Karp M, Parini, C. (2008b). Implication of an outer surface lipoprotein in adhesion of

994 Bifidobacterium bifidum to Caco-2 cells. Appl Environ Microbiol, 74, 4695-4702.

995 Guglielmetti S, Mora D, Gschwender M, Popp K. (2011). Randomised clinical trial:

996 Bifidobacterium bifidum MIMBb75 significantly alleviates irritable bowel syndrome

997 and improves quality of life -a double-blind, placebo-controlled study. Aliment

998 Pharmacol Ther, 33, 1123-32.

999 Hamaji Y, Fujimori M, Sasaki T, Matsuhashi H, Matsui-Seki K, Shimatani-Shibata Y,

1000 Kano Y, Amano J, Taniguchi S. (2007). Strong enhancement of recombinant

1001 cytosine deaminase activity in Bifidobacterium longum for tumor-targeting

1002 enzyme/prodrug therapy. Biosci Biotechnol Biochem, 71, 874-83.

1003 Hartke A, Benachour A, Bouibonnes P, Auffray Y. (1996). Characterisation of a

1004 complex restriction/modification system detected in a Bifidobacterium longum strain.

1005 Appl Microbiol Biotechnol, 45, 132-6.

1006 Hayes F. (2003). The function and organization of plasmids. Methods Mol Biol, 235,

$1007 \quad 1-17$.

1008 Hendrix RW, Smith MCM, Burns RN, Ford ME, Hatfull GF. (1999). Evolutionary

1009 relationships among diverse bacteriophages and prophages: all the world's a phage.

$1010 \quad$ Proc Natl Acad Sci USA, 96, 2192-7.

1011 Hidaka A, Hamaji Y, Sasaki T, Taniguchi S, Fujimori M. (2007). Exogenous cytosine

1012 deaminase gene expression in Bifidobacterium breve I-53-8w for tumor-targeting

1013 enzyme/prodrug therapy. Biosci Biotechnol Biochem, 71, 2921-6. 
1014 Hou X, Liu JE. (2006). Construction of Escherichia coli-Bifidobacterium longum

1015 shuttle vector and expression of tumor suppressor gene PTEN in B. longum. Wei

1016 Sheng Wu Xue Bao, 46, 347-52.

1017 Hu B, Kou L, Li C, Zhu LP, Fan YR, Wu ZW, Wang JJ, Xu GX. (2009).

1018 Bifidobacterium longum as a delivery system of TRAIL and endostatin cooperates

1019 with chemotherapeutic drugs to inhibit hypoxic tumor growth. Cancer Gene Ther, 16,

$1020 \quad 655-63$.

1021 Ishikawa H, Matsumoto S, Ohashi Y, Imaoka A, Setoyama H, Umesaki Y, Tanaka R,

1022 Otani T. (2011). Beneficial effects of probiotic bifidobacterium and galacto-

1023 oligosaccharide in patients with ulcerative colitis: a randomized controlled study.

1024 Digestion, 84, 128-33.

1025 Ivanov D, Emonet C, Foata F, Affolter M, Delley M, Fisseha M, Blum-Sperisen S,

1026 Kochhar S, Arigoni F. (2006) A serpin from the gut bacterium Bifidobacterium

1027 longum inhibits eukaryotic elastase-like serine proteases. J Biol Chem, 281, 17246-

102852.

1029 Iwata M, Morishita T. (1989). The presence of plasmids in Bifidobacterium breve. Lett $1030 \quad$ Appl Microbiol, 9, 165-8.

1031 Ji GE, Park MS, Kang YH, Seo JM. (2005). Plasmid originated from Bifidobacterium,

1032 recombinant expression vector using the plasmid and transformation method. United

1033 States Patent 6887702.

1034 Kazimierczak KA, Flint HJ, Scott KP. (2006). Comparative analysis of sequences

1035 flanking tet $(\mathrm{W})$ resistance genes in multiple species of gut bacteria. Antimicrob

1036 Agents Chemother, 50, 2632-9. 
1037 Khokhlova EV, Efimov BA, Kafarskaia LI, Shkoporov AN. (2010). Heterologous

1038 expression of secreted biologically active human interleukin-10 in Bifidobacterium

1039 breve. Arch Microbiol, 192, 769-74.

1040 Kim JF, Jeong H, Yu DS, Choi SH, Hur CG, Park MS, Yoon SH, Kim DW, Ji GE,

1041 Park HS, Oh TK. (2009). Genome sequence of the probiotic bacterium

1042 Bifidobacterium animalis subsp. lactis AD011. J Bacteriol, 191, 678-9.

1043 Kim JY, Wang Y, Park MS, Ji GE. (2010). Improvement of transformation efficiency

1044 through in vitro methylation and SacII site mutation of plasmid vector in

1045 Bifidobacterium longum MG1. J Microbiol Biotechnol, 20, 1022-6.

1046 Kimura NT, Taniguchi S, Aoki K. (1980). Selective localization and growth of

1047 Bifidobacterium bifidum in mouse tumors following intravenous administration.

1048 Cancer Res, 40, 2061-8.

1049 Klijn A, Moine D, Delley M, Mercenier A, Arigoni F, Pridmore RD. (2006).

1050 Construction of a reporter vector for the analysis of Bifidobacterium longum

1051 promoters. Appl Environ Microbiol, 72, 7401-5.

1052 Kullen MJ, Klaenhammer TR. (2000). Genetic modification of intestinal lactobacilli

1053 and bifidobacteria. Curr Issues Mol Biol, 2, 41-50.

1054 Leahy SC, Higgins DG, Fitzgerald G F, van Sinderen D. (2005). Getting better with

1055 bifidobacteria. J Appl Microbiol, 98, 1303-15.

1056 LeDeaux JR, Grossman AD. (1995). Isolation and characterization of kinC, a gene that

1057 encodes a sensor kinase homologous to the sporulation sensor kinases KinA and

1058 KinB in Bacillus subtilis. J Bacteriol, 177, 166-75.

1059 Lee JH, O’Sullivan DJ. (2006). Sequence analysis of two cryptic plasmids from

1060 Bifidobacterium longum DJO10A and construction of a shuttle cloning vector. Appl

1061 Environ Microbiol, 72, 527-35. 
1062 Lee JH, Karamychev VN, Kozyavkin SA, Mills D, Pavlov AR, Pavlova NV,

1063 Polouchine NN, Richardson PM, Shakhova VV, Slesarev AI, Weimer B, O'Sullivan

1064 DJ. (2008). Comparative genomic analysis of the gut bacterium Bifidobacterium

1065 longum reveals loci susceptible to deletion during pure culture growth. BMC

1066 Genomics, 9, 247.

1067 Li X, Fu GF, Fan YR, Liu WH, Liu XJ, Wang JJ, Xu GX.(2003). Bifidobacterium

1068 adolescentis as a delivery system of endostatin for cancer gene therapy: selective

1069 inhibitor of angiogenesis and hypoxic tumor growth. Cancer Gene Ther, 10, 105-11.

1070 Long RT, Zeng WS, Chen LY, Guo J, Lin YZ, Huang QS, Luo SQ. (2010).

1071 Bifidobacterium as an oral delivery carrier of oxyntomodulin for obesity therapy:

1072 inhibitory effects on food intake and body weight in overweight mice. Int J Obes

1073 (Lond), 34, 712-9.

1074 MacConaill LE, Fitzgerald GF, van Sinderen D. (2003). Investigation of protein export

1075 in Bifidobacterium breve UCC2003. Appl Environ Microbiol, 69, 6994-7001.

1076 Malmgren RA, Flanigan CC. (1955). Localization of the vegetative from of

1077 Clostridium tetani in mouse tumors following intravenous spore administration.

$1078 \quad$ Cancer Res, 15, 473-8.

1079 Martín MC, Alonso JC, Suárez JE, Álvarez MA. (2000). Generation of food-grade

1080 recombinant lactic acid bacterium strains by site-specific recombination. Appl

1081 Environ Microbiol, 66, 2599-2604.

1082 Matsumura H, Takeuchi A, Kano Y. (1997). Construction of Escherichia coli-

1083 Bifidobacterium longum shuttle vector transforming B. longum 105-A and 108-A.

1084 Biosci Biotechnol Biochem, 61, 1211-2.

1085 Matteuzzi D, Sozzi T. (1970). Bifidobacterium bacteriophage from calf rumen.

1086 Zeitschrift für Allg Mikrobiologie, 11, 57-8. 
1087 Missich R, Sgorbati B, Leblanc DJ. (1994). Transformation of Bifidobacterium longum

1088 with pRM2, a constructed Escherichia coli-B. longum shuttle vector. Plasmid, 32,

$1089 \quad 208-11$.

1090 Moon GS, Pyun YR, Park MS, Ji GE, Kim WJ. (2005). Secretion of recombinant

1091 pediocin PA-1 by Bifidobacterium longum, using the signal sequence for

1092 bifidobacterial alpha-amylase. Appl Environ Microbiol, 71, 5630-2.

1093 Moon GS, Wegmann U, Gunning AP, Gasson MJ, Narbad A. (2009). Isolation and

1094 characterization of a Theta-type cryptic plasmid from Bifidobacterium longum

1095 FI10564. J Microbiol Biotechnol, 19, 403-8.

1096 Mueller S, Saunier K, Hanisch C, Norin E, Alm L, Midtvedt T, Cresci A, Silvi S,

1097 Orpianesi C, Verdenelli MC, Clavel T, Koebnick C, Zunft HJ, Doré J, Blaut M.

1098 (2006). Differences in fecal microbiota in different European study populations in

1099 relation to age, gender, and country: a cross-sectional study. Appl Environ Microbiol,

$1100 \quad 72,1027-33$.

1101 Nakamura T, Sasaki T, Fujimori M, Yazawa K, Kano Y, Amano J, Taniguchi S.

1102 (2002). Cloned cytosine deaminase gene expression of Bifidobacterium longum and

1103 application to enzyme/pro-drug therapy of hypoxic solid tumors. Biosci Biotechnol

1104 Biochem, 66, 2362-6.

1105 O’Connell Motherway M, Fitzgerald GF, Neirynck S, Ryan S, Steidler L, van Sinderen

1106 D. (2008). Characterization of ApuB, an extracellular type II amylopullulanase from

1107 Bifidobacterium breve UCC2003. Appl Environ Microbiol, 74, 6271-9.

1108 O’Connell Motherway M, O’Driscoll J, Fitzgerald GF, van Sinderen D. (2009).

1109 Overcoming the restriction barrier to plasmid transformation and targeted

1110 mutagenesis in Bifidobacterium breve UCC2003. Microbial Biotechnol, 2, 321-32. 
1111 O'Connell Motherway M, Zomer A, Leahy SC, Reunanen J, Bottacini F, Claesson MJ,

1112 O'Brien F, Flynn K, Casey PG, Munoz JA, Kearney B, Houston AM, O'Mahony C,

1113 Higgins DG, Shanahan F, Palva A, de Vos WM, Fitzgerald GF, Ventura M, O'Toole

1114 PW, van Sinderen D. (2011a). Functional genome analysis of Bifidobacterium breve

1115 UCC2003 reveals type IVb tight adherence (Tad) pili as an essential and conserved

1116 host-colonization factor. Proc Natl Acad Sci U S A, 108, 11217-22.

1117 O’Connell Motherway M, Fitzgerald GF, van Sinderen D. (2011b). Metabolism of a

1118 plant derived galactose-containing polysaccharide by Bifidobacterium breve

1119 UCC2003. Microbial Biotechnol, 4, 403-10.

1120 O’Riordan K, Fitzgerald GF. (1999). Molecular characterisation of a 5.75-kb cryptic

1121 plasmid from Bifidobacterium breve NCFB 2258 and determination of mode of

1122 replication. FEMS Microbiol Lett, 174, 285-94.

1123 Park KB, Ji GE, Park MS, Oh SH. (2005a). Expression of rice glutamate decarboxylase

1124 in Bifidobacterium longum enhances gamma-aminobutyric acid production.

1125 Biotechnol Lett, 27, 1681-4.

1126 Park MS, Lee KH, Ji GE. (1997). Isolation and characterization of two plasmids from

1127 Bifidobacterium longum. Lett Appl Microbiol, 25, 5-7.

1128 Park MS, Shin DW, Lee KH, Ji GE. (1999). Sequence analysis of plasmid pKJ50 from

1129 Bifidobacterium longum. Microbiol, 145, 585-92.

1130 Park MS, Moon HW, Ji GE. (2003). Molecular characterization of plasmid from

1131 Bifidobacterium longum. J Microbiol Biotechnol, 13, 457-462.

1132 Park MS, Seo JM, Kim JY, Ji GE. (2005b). Heterologous gene expression and

1133 secretion in Bifidobacterium longum. Lait, 85, 1-8. 
1134 Park MS, Kwon B, Shim JJ, Huh CS, Ji GE. (2007). Heterologous expression of

1135 cholesterol oxidase in Bifidobacterium longum under the control of 16S rRNA gene

1136 promoter of bifidobacteria. Biotechnol Lett, 30, 165-172.

1137 Park YS, Kim KH, Park JH, Oh IK, Yoon SS. (2008). Isolation and molecular

1138 characterization of a cryptic plasmid from Bifidobacterium longum. Biotechnol Lett, $113930,145-51$.

1140 Parvez S, Malik KA, Ah Kang S, Kim HY. (2006). Probiotics and their fermented food 1141 products are beneficial for health. J Appl Microbiol, 100, 1171-85.

1142 Philippe H, Douady CJ. (2003) Horizontal gene transfer and phylogenetics. Curr Opin 1143 Microbiol, 6, 498-505.

1144 Pokusaeva K, Neves AR, Zomer A, O'Connell-Motherway M, Macsharry J, Curley P, 1145 Fitzgerald GF, van Sinderen D. (2010). Ribose utilization by the human commensal 1146 Bifidobacterium breve UCC2003. Microb Biotechnol, 3, 311-23.

1147 Pokusaeva K, O’Connell-Motherway M, Zomer A, Macsharry J, Fitzgerald GF, van

1148 Sinderen D. (2011). Cellodextrin utilization by Bifidobacterium breve UCC2003.

1149 Appl Environ Microbiol, 77, 1681-90.

1150 Poquet I, Ehrlich SD, Gruss A. (1998). An export-specific reporter designed for Gram-

1151 positive bacteria: application to Lactococcus lactis. J Bacteriol, 180, 1904-12.

1152 Reyes Escogido ML, De León Rodríguez A, Barba de la Rosa AP. (2007). A novel

1153 binary expression vector for production of human IL-10 in Escherichia coli and

1154 Bifidobacterium longum. Biotechnol Lett, 29, 1249-53.

1155 Rhim SL, Park MS, Ji GE. (2006). Expression and secretion of Bifidobacterium

1156 adolescentis amylase by Bifidobacterium longum. Biotechnol Lett, 23, 163-8. 
1157 Roberts AP, Chandler M, Courvalin P, Guédon G, Mullany P, Pembroke T, Rood JI,

1158 Smith CJ, Summers AO, Tsuda M, Berg DE. (2008). Revised nomenclature for

1159 transposable genetic elements. Plasmid, 60, 167-73.

1160 Roberts RJ. (1980). Restriction and modification enzymes and their recognition

1161 sequences. Nucleic Acids Res, 8, r63-r80.

1162 Rossi M, Brigidi P, Gonzalez Vara y Rodriguez A, Matteuzzi D. (1996).

1163 Characterization of the plasmid pMB1 from Bifidobacterium longum and its use for

1164 shuttle vector construction. Res Microbiol, 147, 133-43.

1165 Rossi M, Brigidi P, Matteuzzi D. (1997). An efficient transformation system for

1166 Bifidobacterium spp. Lett Appl Microbiol, 24, 33-6.

1167 Rossi M, Brigidi P, Matteuzzi D. (1998). Improved cloning vectors for

1168 Bifidobacterium spp. Lett Appl Microbiol, 26, 101-4.

1169 Sangrador-Vegas A, Stanton C, van Sinderen D, Fitzgerald GF, Ross RP. (2007).

1170 Characterization of plasmid pASV479 from Bifidobacterium pseudolongum subsp.

1171 globosum and its use for expression vector construction. Plasmid, 58, 140-7.

1172 Sasaki T, Fujimori M, Hamaji Y, Hama Y, Ito K, Amano J, Taniguchi S. (2006).

1173 Genetically engineered Bifidobacterium longum for tumor-targeting enzyme-prodrug

1174 therapy of autochthonous mammary tumors in rats. Cancer Sci, 97, 649-57.

1175 Scardovi V. (1986). Genus Bifidobacterium. Orla-Jensen 1924, 472AL. In: Sneath PHA,

1176 Mair NS, Sharpe ME, Holt JG, eds, Bergey’s Manual of Systematic Bacteriology,

1177 Vol. 2, Baltimore: Williams and Wilkins, 1418-34.

1178 Schell MA, Karmirantzou M, Snel B, Vilanova D, Berger B, Pessi G, Zwahlen MC,

1179 Desiere F, Bork P, Delley M, Pridmore RD, Arigoni F. (2002). The genome sequence

1180 of Bifidobacterium longum reflects its adaptation to the human gastrointestinal tract.

$1181 \quad$ Proc Natl Acad Sci USA, 99, 14422-7. 
1182 Sela DA, Chapman J, Adeuya A, Kim JH, Chen F, Whitehead TR, Lapidus A, Rokhsar

1183 DS, Lebrilla CB, German JB, Price NP, Richardson PM, Mills DA. (2008). The

1184 genome sequence of Bifidobacterium longum subsp. infantis reveals adaptations for

1185 milk utilization within the infant microbiome. Proc Natl Acad Sci USA, 105, 18964-

11869

1187 Serafini F, Turroni F, Guglielmetti S, Gioiosa L, Foroni E, Sanghez V, Bartolomucci

1188 A, Motherway MO, Palanza P, van Sinderen D, Ventura M. An efficient and

1189 reproducible method for transformation of genetically recalcitrant bifidobacteria.

1190 FEMS Microbiol Lett. 2012 May 28. doi: 10.1111/j.1574-6968.2012.02605.x.

1191 Sgorbati B, Scardovi V, Leblanc DJ. (1982). Plasmids in the genus Bifidobacterium. J

1192 Gen Microbiol, 128, 2121-31.

1193 Sgorbati B, Smiley MB, Sozzi T. (1983). Plasmids and phages in Bifidobacterium

1194 longum. Microbiologica, 6, 169-73.

1195 Shkoporov AN, Efimov BA, Khokhlova EV, Steele JL, Kafarskaia LI, Smeianov VV.

1196 (2008a). Characterization of plasmids from human infant Bifidobacterium strains:

1197 sequence analysis and construction of E. coli-Bifidobacterium shuttle vectors.

1198 Plasmid, 60, 136-48.

1199 Shkoporov AN, Efimov BA, Khokhlova EV, Kafarskaia LI, Smeianov VV. (2008b).

1200 Production of human basic fibroblast growth factor (FGF-2) in Bifidobacterium

1201 breve using a series of novel expression/secretion vectors. Biotechnol Lett, 30, 1983-

12028.

1203 Siefert JL. (2009). Defining the mobilome. Methods Mol Biol, 532, 13-27.

1204 Siezen RJ, Renckens B, van Swam I, Peters S, van Kranenburg R, Klerebeezem M, de

1205 Vos WM. (2005). Complete sequences of four plasmids of Lactococcus lactis subsp. 

cremoris SK11 reveal extensive adaptation to the dairy environment. Appl Environ 1207 Microbiol, 71, 8371-82.

1208 Simon R, Priefer U, Puhler A. (1983). A broad host range mobilization system for in 1209 vivo genetic engineering: transposon mutagenesis in Gram-negative bacteria. $1210 \quad$ Bio/Technology, 1, 784-91.

1211 Stanton C, Gardiner G, Meehan H, Collins K, Fitzgerald G, Lynch PB, Ross RP. 1212 (2001). Market potential for probiotics. Am J Clin Nutr, 73, 476S-83S.

1213 Takata T, Shirakawa T, Kawasaki Y, Kinoshita S, Gotoh A, Kano Y, Kawabata M. 1214 (2006). Genetically engineered Bifidobacterium animalis expressing the Salmonella 1215 flagellin gene for the mucosal immunization in a mouse model. J Gene Med, 8, 1341$1216 \quad 6$.

1217 Tanaka K, Samura K, Kano Y. (2005). Structural and functional analysis of pTB6 from 1218 Bifidobacterium longum. Biosci Biotechnol Biochem, 69, 422-5.

1219 Tang W, He Y, Zhou S, Ma Y, Liu G. (2009). A novel Bifidobacterium infantis1220 mediated TK/GCV suicide gene therapy system exhibits antitumor activity in a rat 1221 model of bladder cancer. J Exp Clin Cancer Res, 28, 155.

1222 Tauch A, Kassing F, Kalinowski J, Pühler A. (1995). The Corynebacterium xerosis 1223 composite transposon Tn5432 consists of two identical insertion sequences, 1224 designated IS1249, flanking the erythromycin resistance gene ermCX. Plasmid, 34, $1225 \quad 119-31$.

1226 Thomas CM. (2004). Evolution and population genetics of bacterial plasmids. In:

1227 Funnel BE, Phillips GJ, eds, Plasmid Biology. Washington: ASM Press, 509-528.

1228 Tuohy KM, Probert HM, Smejkal CW, Gibson GR. (2003). Using probiotics and 1229 prebiotics to improve gut health. Drug Discov Today, 8, 692-700. 
1230 Turroni F, van Sinderen D, Ventura M. (2009). Bifidobacteria: from ecology to

1231 genomics. Front Biosci, 14, 4673-84.

1232 Turroni F, Foroni E, O'Connell Motherway M, Bottacini F, Giubellini V, Zomer A,

1233 Ferrarini A, Delledonne M, Zhang Z, van Sinderen D, Ventura M. (2010).

1234 Characterization of the serpin-encoding gene of Bifidobacterium breve 210B. Appl

1235 Environ Microbiol, 76, 3206-19.

1236 Turroni F, Peano C, Pass DA, Foroni E, Severgnini M, Claesson MJ, Kerr C,

1237 Hourihane J, Murray D, Fuligni F, Gueimonde M, Margolles A, De Bellis G,

1238 O'Toole PW, van Sinderen D, Marchesi JR, Ventura M. (2012). Diversity of

1239 bifidobacteria within the infant gut microbiota. PLoS One, 7, e36957.

1240 van Hoek AHAM, Mayrhofer S, Domig KJ, Aarts HJM. (2008). Resistance

1241 determinant erm $(\mathrm{X})$ is borne by transposon Tn5432 in Bifidobacterium thermophilum

1242 and Bifidobacterium animalis subsp. lactis. Int J Antimicrob Agents, 31, 544-8.

1243 Ventura M, van Sinderen D, Fitzgerald GF, Zink R. (2004) Insights into the taxonomy,

1244 genetics and physiology of bifidobacteria. Antonie van Leeuwenhoek, 86, 205-23.

1245 Ventura M, Lee JH, Canchaya C, Zink R, Leahy S, Moreno-Muñoz JA, O’Connell-

1246 Motherway M, Higgins D, Fitzgerald GF, O’Sullivan DJ, van Sinderen D. (2005).

1247 Prophage-like elements in bifidobacteria: insights from genomics, transcription,

1248 integration, distribution, and phylogenetic analysis. Appl Environ Microbiol, 71,

$1249 \quad 8692-705$

1250 Ventura M, Canchaya C, Tauch A, Chandra G, Fitzgerald GF, Chater KF, van

1251 Sinderen D. (2007). Genomics of Actinobacteria: tracing the evolutionary history of

1252 an ancient phylum. Microbiol Mol Biol Rev, 71, 495-548. 
1253 Ventura M, O'Flaherty S, Claesson MJ, Turroni F, Klaenhammer TR, van Sinderen D,

1254 O'Toole PW. (2009). Genome-scale analyses of health-promoting bacteria:

1255 probiogenomics. Nat Rev Microbiol. Jan;7(1):61-71.

1256 Ventura M, Turroni F, Zomer A, Foroni E, Giubellini V, Bottacini F, Canchaya C,

1257 Claesson MJ, He F, Mantzourani M, Mulas L, Ferrarini A, Gao B, Delledonne M,

1258 Henrissat B, Coutinho P, Oggioni M, Gupta RS, Zhang Z, Beighton D, Fitzgerald

1259 GF, O'Toole PW, van Sinderen D. (2009b). The Bifidobacterium dentium Bd1

1260 genome sequence reflects its genetic adaptation to the human oral cavity. PLoS

$1261 \quad$ Genet, 5, e1000785.

1262 Watson D, Sleator RD, Hill C, Gahan CG. (2008). Enhancing bile tolerance improves

1263 survival and persistence of Bifidobacterium and Lactococcus in the murine

1264 gastrointestinal tract. BMC Microbiol, 8, 176.

1265 Xu YF, Zhu LP, Hu B, Fu GF, Zhang HY, Wang JJ, Xu GX. (2007). A new expression

1266 plasmid in Bifidobacterium longum as a delivery system of endostatin for cancer

1267 gene therapy. Cancer Gene Ther, 14, 151-7.

1268 Yamamoto S, Wada J, Katayama T, Jikimoto T, Nakamura M, Kinoshita S, Lee KM,

1269 Kawabata M, Shirakawa T. (2010). Genetically modified Bifidobacterium displaying

1270 Salmonella-antigen protects mice from lethal challenge of Salmonella Typhimurium

1271 in a murine typhoid fever model. Vaccine, 28, 6684-91.

1272 Yasui K, Kano Y, Tanaka K, Watanabe K, Shimizu-Kadota M, Yoshikawa H, Suzuki

1273 T. (2009). Improvement of bacterial transformation efficiency using plasmid artificial

1274 modification. Nucleic Acids Res, 37, e3.

1275 Yazawa K, Fujimori M, Amano J, Kano Y, Taniguchi S. (2000). Bifidobacterium

1276 longum as a delivery system for cancer gene therapy: selective localization and

1277 growth in hypoxic tumors. Cancer Gene Ther, 7, 269-74. 
1278 Yazawa K, Fujimori M, Nakamura T, Sasaki T, Amano J, Kano Y, Taniguchi S.

1279 (2001). Bifidobacterium longum as a delivery system for gene therapy of chemically

1280 induced rat mammary tumors. Breast Cancer Res Treat, 66, 165-70.

1281 Yi C, Huang Y, Guo ZY, Wang SR. (2005). Antitumor effect of cytosine deaminase/5-

1282 fluorocytosine suicide gene therapy system mediated by Bifidobacterium infantis on 1283 melanoma. Acta Pharmacol Sin, 26, 629-34.

1284 Yildirim Z, Winters DK, Johnson MG. (1999). Purification, amino acid sequence and 1285 mode of action of bifidocin B produced by Bifidobacterium bifidum NCFB 1454. J 1286 App Microbiol, 86, 45-54.

1287 Youseff M, Müller-Beuthow W, Haenel H. (1966). Isolierung von Backeiophagen für 1288 anaerobe Laktobazillen aus dem Sthul des Menschen. Naturwissenchafen, 53, 589.

1289 Yu Z, Zeng Z, Huang Z, Lian J, Yang J, Deng Q, Zeng W. (2010). Increased mRNA

1290 expression of interferon-induced Mx1 and immunomodulation following oral

1291 administration of IFN-alpha2b-transformed B. longum to mice. Arch Microbiol, 192, 1292 633-8. Epub 2010 Jun 10. PubMed PMID: 20535450.

1293 Yu Z, Huang Z, Shao C, Huang Y, Zhang F, Yang J, Deng L, Zeng Z, Deng Q, Zeng

1294 W. (2011). Oral administration of interferon- $\alpha 2$ b-transformed Bifidobacterium

1295 longum protects BALB/c mice against coxsackievirus B3-induced myocarditis. Virol $1296 \quad \mathrm{~J}, 8,525$.

1297 Yu Z, Huang Z, Sao C, Huang Y, Zhang F, Yang J, Lian J, Zeng Z, Luo W, Zeng W, 1298 Deng Q. (2012). Bifidobacterium as an oral delivery carrier of interleukin-12 for the 1299 treatment of Coxsackie virus B3-induced myocarditis in the Balb/c mice. Int

1300 Immunopharmacol, 12, 125-30.

1301 Zhang ZQ, Yao LH, Hou YD. (1990). Construction and application of a high level 1302 expression vector containing $\mathrm{P}_{\mathrm{R}} \mathrm{P}_{\mathrm{L}}$ promotor. Chin J Virol, 6, 111-6. 
1303 Zhu LP, Yin Y, Xing J, Li C, Kou L, Hu B, Wu ZW, Wang JJ, Xu GX. (2009).

1304 Therapeutic efficacy of Bifidobacterium longum-mediated human granulocyte

1305 colony-stimulating factor and/or endostatin combined with cyclophosphamide in

1306 mouse-transplanted tumors. Cancer Sci, 100, 1986-90.

1307 


\section{Figure Legends}

1309 Fig. 1. Trees produced by BLAST (http://blast.ncbi.nlm.nih.gov/Blast.cgi) using a

1310 pairwise alignment between a query (an arbitrarily selected Rep protein from a

1311 Bifidobacterium plasmid) and the database sequences searched. Type I: this group

1312 includes 18 Rep proteins from Bifidobacterium plasmids. Plasmids without species

1313 indication belong to Bifidobacterium longum susp. longum. Types II-VI: Rep stands for

1314 replication initiation protein. Types II and IV: Bifidobacterium longum stands for

1315 Bifidobacterium longum susp. longum. CFB stands for the bacterial group Cytophaga-

1316 Flavobacterium-Bacteroides. Red triangles evidence Rep proteins from

1317 Bifidobacterium plasmids.

1318 Fig. 2. Linear functional maps of a representative plasmid from all the Bifidobacterium

1319 plasmid structures up to now recognized (in accordance with Table 1). In these maps,

1320 all the open reading frames from Bifidobacterium plasmids with a putatively assigned

1321 biological function are included. Dotted arrows refer to hypothetical conserved

1322 proteins with unknown function. Genes represented with the same colors/motif share a

1323 significant sequence similarity. Genes represented with white arrows are harbored by

1324 only one of the shown plasmids. Rep typology in accordance to Fig. 1 is indicated

1325 between brackets.

1326 Legend of the gene symbols indicated in the maps. rep, gene encoding a

1327 replication initiation protein. $m o b$, gene encoding a putative plasmid mobilization

1328 protein. memb, gene encoding an integral transmembrane protein. $\operatorname{tnp} B$, gene encoding

1329 for the transposase of an insertion sequence-like element of the IS200/IS605 family,

1330 named ISBlo15. tra, transposase gene. trw, gene encoding for a putative protein

1331 containing the conjugative relaxase domain TrwC/TraI (Conserved Domain Database,

1332 CDD, accession code TIGR02686). fts $K$-like gene, gene putatively encoding for a 
1333 domain of the FtsK/SpoIIIE family. This domain contains a putative ATP binding P-

1334 loop motif. A mutation in FtsK causes a temperature sensitive block in cell division

1335 and it is involved in peptidoglycan synthesis or modification. The SpoIIIE protein is

1336 implicated in intercellular chromosomal DNA transfer (CDD accession code

1337 pfam01580). tet $(\mathrm{Q})$, tetracycline resistance gene encoding a ribosomal protection

1338 protein. $\operatorname{cop} G$, orf ecoding a putative protein that shares similarity with the plasmid

1339 pMV158-encoded transcriptional repressor CopG (CDD accession code pfam01402).

1340 par, gene encoding for a putative protein belonging to the ParA conserved family of

1341 bacterial proteins (CDD accession code cd02042), implicated in chromosome

1342 segregation (involved in the plasmid replication and partition). RE gene, gene encoding

1343 a putative protein with a type II restriction endonuclease domain (EcoRII, CDD

1344 accession code pfam09019). peptidase gene, encoding for a putative member of

1345 peptidase family C39 (cd02549). Peptidase family C39 mostly contains bacteriocin-

1346 processing endopeptidases from bacteria. $m o b A$ and $m o b B$, mobilization protein genes

1347 harbored by plasmids from the Cytophaga-Flavobacterium-Bacteroides group of 1348 bacteria.

1349 Fig. 3. Strategies for the preparation of vector DNA to introduce by electroporation in

1350 bifidobacteria. (A) Conventional strategy, involving the extraction of shuttle vector

1351 DNA from E. coli and direct introduction in Bifidobacterium cells. (B) Plasmid

1352 Artificial Modification (PAM) strategy: 1 - preparation of the PAM host, consisting of

1353 an appropriate E. coli strain (e.g. E. coli TOP10) harbouring PAM vector (a low copy

1354 number vector coding for the methylase(s) of the target host); 2 - introduction of an $E$.

1355 coli-Bifidobacterium shuttle vector into the PAM host; 3 - modification of shuttle

1356 vector DNA by methylase(s) coded by PAM vector; 4 - extraction of the now

1357 methylated vector and 5 - introduction into the target host (Bifidobacterium) by 
1358 electroporation; 6 - target host restriction system(s) cannot digest the methylated 1359 shuttle vector; 7 - shuttle vector replicates inside target host. 


\begin{tabular}{|c|c|c|c|c|c|}
\hline Bifidobacterium species $^{1}$ & Strain & Plasmid & Size (bp) & $\begin{array}{c}\text { Putative replication } \\
\text { mechanism (Rep type }{ }^{2} \text { ) }\end{array}$ & Reference/GenBank accession number \\
\hline B. asteroides & DSM20089 & pCIBAO89 & 2111 & Theta $(I I)$ & Cronin et al. 2007 / EU030683 \\
\hline B. asteroides & DSM20089 & pAP1 & 2140 & Theta $(I I)$ & Y11549 \\
\hline B. bifidum & B80 & pB80 & 4898 & $\mathrm{RC}(I a)$ & Shkoporov et al. 2008a / DQ305402 \\
\hline B. bifidum & ССТСС М203049 & pBIF10 & 9275 & $\mathrm{RC}(I V)$ & DQ093580 \\
\hline B. breve & NCFB2258 & pCIBb1 & 5750 & $\mathrm{RC}(I I I)$ & O’Riordan and Fitzgerald 1999 / AF085719 \\
\hline B. breve & B21a & $\mathrm{pB} 21 \mathrm{a}$ & 5206 & $\mathrm{RC}(I I I)$ & Shkoporov et al. 2008a / DQ497626 \\
\hline B. breve & - & pNBb1 & 2297 & $\mathrm{RC}(I I I)$ & E17316 \\
\hline B. catenulatum & $\mathrm{L} 48$ & $\mathrm{pBC} 1$ & 2540 & Theta $(V)$ & Alvarez-Martin et al. 2007 / DQ011664 \\
\hline B. longum & $\mathrm{KJ}$ & pKJ36 & 3625 & $\mathrm{RC}(I b)$ & Park et al. 1997 / AF139129 \\
\hline B. longum & $\mathrm{KJ}$ & pKJ50 & 4960 & $\mathrm{RC}(I a)$ & Park et al. 1999 / BLU76614 \\
\hline B. longum & NCC2705 & pBLO1 & 3626 & $\mathrm{RC}(I b)$ & Schell et al. 2002 / AF540971 \\
\hline B. longum & MG1 & pMG1 & 3682 & $\mathrm{RC}(\mathrm{Ib})$ & Park et al. 2003 / AY210701 \\
\hline B. longum & RW048 & pNAC1 & 3538 & $\mathrm{RC}(I a)$ & Corneau et al. 2004 / AY112724 \\
\hline B. longum & RW041 & pNAC2 & 3684 & $\mathrm{RC}(I b)$ & Corneau et al. 2004 / AY112723 \\
\hline B. longum & RW041 & pNAC3 & 10224 & Theta $(I I)$ & Corneau et al. 2004 / AY112722 \\
\hline B. longum & BK51 & pTB6 & 3624 & $\mathrm{RC}(I b)$ & Tanaka et al. 2005 / AB187597 \\
\hline B. longum & B2577 & pMB1 & 1847 & Theta $(V)$ & Rossi et al. 2006 / X84655 \\
\hline B. longum & DJO10A & pDOJH10L 3 & 10073 & Theta $(I I)$ & Lee and O'Sullivan 2006 / AF538868 \\
\hline B. longum & DJO10A & pDOJH10S & 3661 & Theta $(V)$ & Lee and O'Sullivan 2006 / AF538869 \\
\hline B. longum & NAL8 & pNAL8L & 3489 & $\mathrm{RC}(I a)$ & Guglielmetti et al. 2007 / AM183145 \\
\hline B. longum & NAL8 & pNAL8M & 4910 & $\mathrm{RC}(I a)$ & Guglielmetti et al. 2007 / AM183144 \\
\hline B. longum & VMKB44 & pB44 & 3624 & $\mathrm{RC}(I b)$ & Shkoporov et al. 2008a / AY066026 \\
\hline B. longum & FI10564 & pFI2576 & 2197 & Theta $(V)$ & Moon et al. 2009 / DQ452864 \\
\hline B. longum & BK28 & pBK283 & 4537 & $\mathrm{RC}(I a)$ & Fukiya et al. 2010 / AB495342 \\
\hline B. longum & DPC6043 & p6043A & 4896 & $\mathrm{RC}(I a)$ & DQ458911 \\
\hline B. longum & DPC6043 & p6043B & 3680 & $\mathrm{RC}(I b)$ & DQ458910 \\
\hline B. longum & M62 & pSP02 & 4896 & $\mathrm{RC}(I a)$ & GU256055 \\
\hline B. pseudocatenulatum & VMKB4M & $\mathrm{p} 4 \mathrm{M}$ & 4488 & $\mathrm{RC}(V I)$ & Gibbs et al. 2006 / AF359574 \\
\hline B. pseudolongum subsp. globosum & DPC479 & pASV479 & 4815 & $\mathrm{RC}(I I I)$ & Sangrador-Vegas et al. 2007 / DQ103758 \\
\hline Bifidobacterium sp. & A24 & pBIFA24 & 4892 & $\mathrm{RC}(I a)$ & Park et al. 2008 / DQ286581 \\
\hline
\end{tabular}

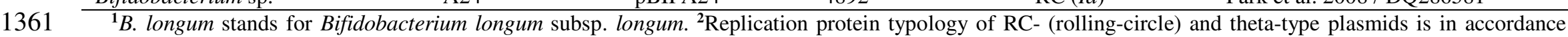

1362 with dendrograms in Fig. $1 .{ }^{3}$ DNA sequence assessment suggests that pDOJH10L is a cointegrate involving plasmids very similar to pKJ50 (96\% identity) and

1363 pNAC2 $(98 \%$ identity) 
1369 Table 2.- Summary of protocols for electrotransformation (electroporation) of bifidobacteria.

\begin{tabular}{|c|c|c|c|c|c|c|c|c|c|}
\hline $\begin{array}{l}\text { Vector } \\
\text { (size, kb) } \\
\text { (marker) }\end{array}$ & Replicon(s) & Growth medium $^{1}$ & $\begin{array}{l}\text { Washing } \\
\text { buffer }\end{array}$ & $\begin{array}{l}\text { Electroporation } \\
\text { buffer }\end{array}$ & Preincubation $^{2}$ & $\begin{array}{l}\text { Voltage and } \\
\text { resistance }\end{array}$ & $\begin{array}{l}\text { Recovering } \\
\text { medium }\end{array}$ & $\begin{array}{l}\text { Transformation rate } \\
\text { (transformants/ } \mu \mathrm{g} \text { DNA) }\end{array}$ & Reference \\
\hline $\begin{array}{l}\text { pDG7 } \\
(7.3 \mathrm{~kb}) \\
\left(\mathrm{Cm}^{\mathrm{R}}\right)\end{array}$ & $\begin{array}{l}\text { pMB1- } \\
\text { pBR322 }\end{array}$ & $\begin{array}{l}\text { MRS, } 0.5 \mathrm{M} \text { sucrose, } \\
0.05 \% \text { cysteine- } \mathrm{HCl} \\
(\mathrm{OD} 600 \mathrm{~nm} 0.2)\end{array}$ & $0.5 \mathrm{M}$ sucrose & $\begin{array}{l}1 \mathrm{mM} \text { ammonium } \\
\text { citrate buffer } \mathrm{pH} 6 \text {, } \\
0.5 \mathrm{M} \text { sucrose }\end{array}$ & $\begin{array}{l}3.5 \mathrm{~h} \text { at } 4^{\circ} \mathrm{C} \text { in } \\
\text { electroporation } \\
\text { buffer }\end{array}$ & $\begin{array}{l}12 \mathrm{kV} / \mathrm{cm} \\
200 \Omega\end{array}$ & $\begin{array}{l}\text { MRS, } \\
0.5 \mathrm{M} \text { sucrose, } \\
0.05 \% \text { cysteine }\end{array}$ & 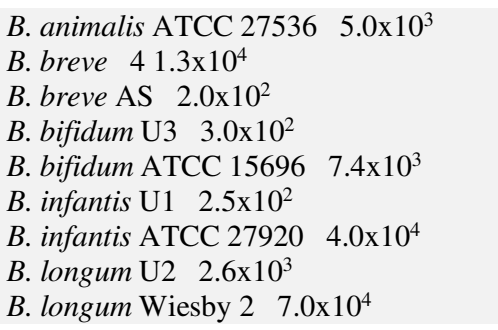 & $\begin{array}{l}\text { Argnani et } \\
\text { al. } 1996\end{array}$ \\
\hline $\begin{array}{l}\text { pNC7 } \\
(4.9 \mathrm{~kb}) \\
\left(\mathrm{Cm}^{\mathrm{R}}\right)\end{array}$ & $\begin{array}{l}\text { pMB1 (non } \\
\text { replicative } \\
\text { in } E \text {. coli) }\end{array}$ & $\begin{array}{l}\text { Iwata Medium (IM; } \\
\text { Iwata and Morishita, } \\
\text { 1989), } \\
16 \% \text { Actilight }{ }^{\circledR} \mathrm{P} \\
\left(\mathrm{OD}_{600 \mathrm{~nm}} 0.2-0.3\right)\end{array}$ & $\begin{array}{l}5 \text { mM K- } \\
\text { phosphate } \\
\text { buffer pH7 }\end{array}$ & 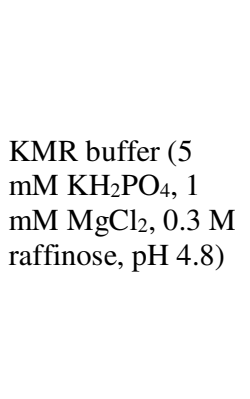 & $\begin{array}{l}\text { Overnight at } \\
0^{\circ} \mathrm{C} \text { in } \\
\text { electroporation } \\
\text { buffer }\end{array}$ & $\begin{array}{l}12.5 \mathrm{kV} / \mathrm{cm} \\
200 \Omega\end{array}$ & $\begin{array}{l}\text { IM, } \\
16 \% \text { Actilight }{ }^{\circledR} P\end{array}$ & 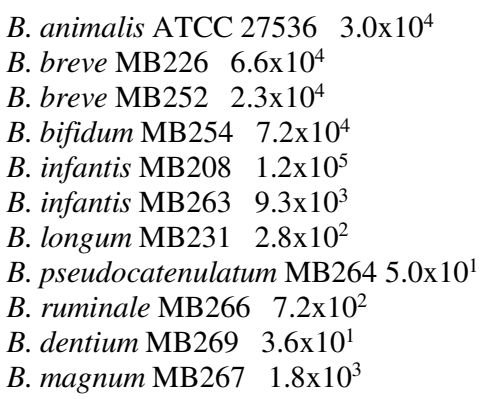 & $\begin{array}{l}\text { Rossi et al. } \\
1997^{3}\end{array}$ \\
\hline $\begin{array}{l}\text { pRM2 } \\
(7.5 \mathrm{~kb}) \\
\left(\mathrm{Sp}^{\mathrm{R}}\right)\end{array}$ & $\begin{array}{l}\text { pMB1- } \\
\text { pBR322 }\end{array}$ & 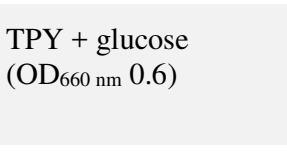 & $10 \%$ glycerol & $10 \%$ glycerol & $\begin{array}{l}\text { Freezing at } \\
-135^{\circ} \mathrm{C} \text { and } \\
\text { storage at } \\
-70^{\circ} \mathrm{C}\end{array}$ & $\begin{array}{l}10 \mathrm{kV} / \mathrm{cm} \\
200 \Omega\end{array}$ & TPY + glucose & B. longum $\mathrm{B} 25773.8 \times 10^{2}$ & $\begin{array}{l}\text { Missich et } \\
\text { al. } 1994\end{array}$ \\
\hline $\begin{array}{l}\text { pBLES100 } \\
(9.1 \mathrm{~kb}) \\
\left(\mathrm{Sp}^{\mathrm{R}}\right)\end{array}$ & $\begin{array}{l}\text { pTB6 }{ }^{4}- \\
\text { pBR322 }\end{array}$ & $\begin{array}{l}\text { Briggs Medium } \\
\text { (Briggs, 1953) } \\
\text { supplemented with } \\
2 \% \text { lactose instead of } \\
\text { glucose } \\
\text { (cells in middle to } \\
\text { late log phase) }\end{array}$ & $10 \%$ glycerol & $10 \%$ glycerol & $\begin{array}{l}\text { Freezing at } \\
-135^{\circ} \mathrm{C} \text { and } \\
\text { storage at } \\
-70^{\circ} \mathrm{C}\end{array}$ & $\begin{array}{l}10 \mathrm{kV} / \mathrm{cm} \\
200 \Omega\end{array}$ & Briggs Medium & B. longum $105-\mathrm{A} \quad 2.2 \times 10^{4}$ & $\begin{array}{l}\text { Matsumura } \\
\text { et al. } 1997\end{array}$ \\
\hline $\begin{array}{l}\text { pBKJ50F } \\
(8.1 \mathrm{~kb}) \\
\left(\mathrm{Cm}^{\mathrm{R}}\right)\end{array}$ & $\begin{array}{l}\text { pKJ50- } \\
\text { pBR322 }\end{array}$ & \multicolumn{6}{|c|}{ According to Argnani et al. (1996). with the only modification of pulse at $10 \mathrm{kV} / \mathrm{cm}$} & B. animalis ATCC $275362.0 \times 10^{2}$ & $\begin{array}{l}\text { Park et al. } \\
1999\end{array}$ \\
\hline $\begin{array}{l}\text { pBES2 } \\
(7.6 \mathrm{~kb}) \\
\left(\mathrm{Cm}^{\mathrm{R}}\right)\end{array}$ & $\begin{array}{l}\mathrm{pMG1}^{4}- \\
\text { pUC } \\
\text { (ColE1) }\end{array}$ & \multicolumn{6}{|c|}{ According to Argnani et al. (1996), with the addition of Oxyrase ${ }^{\circledR}$ (Oxyrase inc. Ohio) in the recovering medium } & B. longum $\mathrm{MG} 1 \quad 7.3 \times 10^{3}$ & $\begin{array}{l}\text { Park et al. } \\
2003\end{array}$ \\
\hline
\end{tabular}




\begin{tabular}{|c|c|c|c|c|c|c|c|c|c|}
\hline $\begin{array}{l}\text { pBRASTA101 } \\
(5.0 \mathrm{~kb}) \\
\left(\mathrm{Sp}^{\mathrm{R}}\right)\end{array}$ & $\begin{array}{l}\text { pTB6 }^{4}- \\
\text { pUC } \\
\text { (ColE1) }\end{array}$ & \multicolumn{6}{|c|}{ According to Missich et al. (1994) and Matsumura et al. (1997) } & B. longum $105-\mathrm{A} 2.5 \times 10^{6}$ & $\begin{array}{l}\text { Tanaka et } \\
\text { al. } 2005\end{array}$ \\
\hline $\begin{array}{l}\text { pFUN } \\
(8.1 \mathrm{~kb}) \\
\left(\text { Ery }^{\mathrm{R}}\right)\end{array}$ & $\begin{array}{l}\text { pAM } \beta 1- \\
\text { (E. faecalis) } \\
\text { pBluescript } \\
\text { (ColE1) }\end{array}$ & $\begin{array}{l}\text { IM, } \\
\text { (Mid-log phase cells, } \\
\text { OD } 600 \mathrm{~nm} 0.5 \text { to } 0.7 \text { ) }\end{array}$ & $\begin{array}{l}0.5 \mathrm{M} \text { sucrose, } \\
1 \mathrm{mM} \text { citrate } \\
\text { buffer (pH 5.8) }\end{array}$ & $\begin{array}{l}0.5 \mathrm{M} \text { sucrose, } \\
1 \mathrm{mM} \text { citrate } \\
\text { buffer (pH 5.8) }\end{array}$ & - & $\begin{array}{l}10 \mathrm{kV} / \mathrm{cm} \\
200 \Omega\end{array}$ & Iwata Medium & B. breve UCC2003 $10^{2}-10^{3}$ & $\begin{array}{l}\text { MacConaill } \\
\text { et al. } 2003\end{array}$ \\
\hline $\begin{array}{l}\text { pPKCm1 } \\
(6.2 \mathrm{~kb}) \\
\left(\mathrm{Cm}^{\mathrm{R}}\right)\end{array}$ & $\begin{array}{l}\text { pCIBA089- } \\
\text { pBluescript } \\
\text { (ColE1) }\end{array}$ & $\begin{array}{l}\text { IM, } \\
\text { (Mid-log phase cells, } \\
\text { OD } 600 \mathrm{~nm} 0.5 \text { to } 0.7 \text { ) }\end{array}$ & $\begin{array}{l}0.5 \mathrm{M} \text { sucrose, } \\
1 \mathrm{mM} \text { citrate } \\
\text { buffer (pH 5.8) }\end{array}$ & $\begin{array}{l}0.5 \mathrm{M} \text { sucrose, } \\
1 \mathrm{mM} \text { citrate } \\
\text { buffer (pH 5.8) }\end{array}$ & - & $\begin{array}{l}10 \mathrm{kV} / \mathrm{cm} \\
200 \Omega\end{array}$ & Iwata Medium & $\begin{array}{l}\text { B. breve UCC2003 } 3.8 \times 10^{6} \\
\text { B. animalis subsp. lactis } \quad 10^{1} \\
\text { B. longum NCIMB8809 } 10^{2} \\
\text { B. pseudolongum NCIMB2244 } 10^{2} \\
\text { B. globosum JCM5820 } 10^{3} \\
\text { B. pseudocatenulatum LMG10505 } 10^{3} \\
\text { B. dentium NCFB2843 } 10^{4}\end{array}$ & $\begin{array}{l}\text { Cronin et } \\
\text { al. } 2007\end{array}$ \\
\hline $\begin{array}{l}\text { pASV480 } \\
(9.0 \mathrm{~kb}) \\
\left(\mathrm{Cm}^{\mathrm{R}}\right)\end{array}$ & $\begin{array}{l}\text { pASV479- } \\
\text { pBluescript } \\
\text { (ColE1) }\end{array}$ & $\begin{array}{l}\text { IM, } \\
\text { (Mid-log phase cells, } \\
\text { OD } 600 \mathrm{~nm} 0.5 \text { to } 0.7 \text { ) }\end{array}$ & $\begin{array}{l}0.5 \mathrm{M} \text { sucrose, } \\
1 \mathrm{mM} \text { citrate } \\
\text { buffer (pH 5.8) }\end{array}$ & $\begin{array}{l}0.5 \mathrm{M} \text { sucrose, } \\
1 \mathrm{mM} \text { citrate } \\
\text { buffer (pH 5.8) }\end{array}$ & - & $\begin{array}{l}10 \mathrm{kV} / \mathrm{cm}, \\
200 \Omega\end{array}$ & $\begin{array}{l}\text { Reinforced } \\
\text { Clostridial } \\
\text { Medium } \\
\text { (RCM) }\end{array}$ & $\begin{array}{l}\text { B. breve NCIMB } 8807 \sim 10^{5} \\
\text { B. breve NCFB } 2258 \sim 10^{5}\end{array}$ & $\begin{array}{l}\text { Sangrador- } \\
\text { Vegas et al. } \\
2007\end{array}$ \\
\hline $\begin{array}{l}\text { pAM4 } \\
(7.6 \mathrm{~kb}) \\
\left(\mathrm{Tet}^{\mathrm{R}}\right)\end{array}$ & $\begin{array}{l}\text { pBC1- } \\
\text { pUC }\end{array}$ & $\begin{array}{l}\text { MRS, } \\
0.05 \% \text { cysteine } \\
\text { (Mid-log phase cells, } \\
\text { OD } 600 \mathrm{~nm} 0.5 \text { to } 0.7 \text { ) }\end{array}$ & $\begin{array}{l}0.5 \mathrm{M} \text { sucrose, } \\
1 \mathrm{mM} \text { citrate } \\
\text { buffer (pH 5.8) }\end{array}$ & $\begin{array}{l}0.5 \mathrm{M} \text { sucrose, } \\
1 \mathrm{mM} \text { citrate } \\
\text { buffer (pH 5.8) }\end{array}$ & $20 \mathrm{~min}$ in ice & $\begin{array}{l}10 \mathrm{kV} / \mathrm{cm} \\
200 \Omega\end{array}$ & $\begin{array}{l}\text { Reinforced } \\
\text { Clostridial } \\
\text { Medium } \\
\text { (RCM) }\end{array}$ & 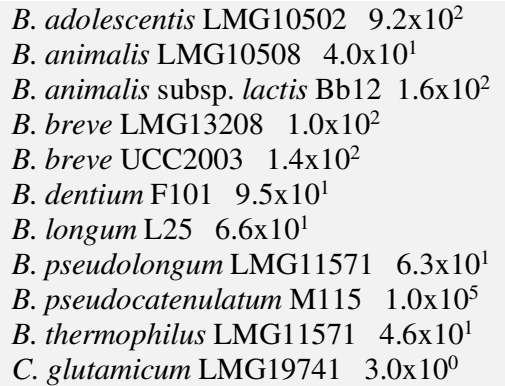 & $\begin{array}{l}\text { Álvarez- } \\
\text { Martín et } \\
\text { al. } 2008\end{array}$ \\
\hline
\end{tabular}

1370 'Phase of growth at which bifidobacterial cells are collected before washing steps.

$1371{ }^{2}$ Incubation step of competent cells before electroporation or storing at $-80^{\circ} \mathrm{C}$.

$1372{ }^{3}$ Trasformation experiments were performed with vector DNA isolated from B. animalis MB209.

1373 "pTB46 and pMG1 plasmids are isogenic to pB44, pNAC2, pBLO1, pDOJ10L, and pKJ36.

1374 B. animalis ATCC 27536 is also known as B. animalis MB209; B. infantis stands for Bifidobacterium longum subsp. infantis.

1375 Key of antibiotic markers: $\mathrm{Cm}^{\mathrm{R}}$, chloramphenicol acetyl transferase $($ cat $)$; $\operatorname{Tet}^{\mathrm{R}}$, tetracycline resistance $[t e t(\mathrm{~W})] ; \mathrm{Sp}^{\mathrm{R}}$, spectinomycin resistance; Ery ${ }^{\mathrm{R}}$, erythromycin

1376 resistance.

1377

1378 
1379 Table 3.- Expression of heterologous genes in bifidobacteria.

\begin{tabular}{|c|c|c|c|c|}
\hline Protein (gene) & Origin & Expression host & Promoter & Reference(s) \\
\hline Cytosine deaminase & E. coli & B. longum 105-A & Promoter of hup gene, coding for the histone like protein of $B$. longum & Nakamura et al. 2002 \\
\hline Secreted nuclease (nис) & Staphylococcus aureus & B. breve UCC2003 & Seven different promoters from B. breve $\mathrm{UCC} 2003$ & MacConaill et al. 2003 \\
\hline $\begin{array}{l}\text { Endostatin (Liver cDNA); TNF-related } \\
\text { apoptosis-inducing ligand (TRAIL) }\end{array}$ & Human & B. adolescentis; B. longum & Coliphage lambda $\mathrm{P}_{\mathrm{R}} \mathrm{P}_{\mathrm{L}}$ promoter regions & $\begin{array}{l}\text { Li et al. 2003; Fu et al. 2005; } \\
\text { Xu et al. 2007; Hu et al., } 2009\end{array}$ \\
\hline $\begin{array}{l}\text { Phytase (appA) fused with the signal } \\
\text { sequence of the } a m y B \text { gene from } B \text {. } \\
\text { adolescentis Int- } 57\end{array}$ & E. coli $\mathrm{MC} 4100$ & B. longum MG1 & Promoter of the $a m y B$ gene from $B$. adolescentis Int- 57 & Park et al. 2005b \\
\hline Green fluorescent protein $(g f p)$ & $\begin{array}{l}\text { Vector pEGFP } \\
\text { (Clontech, USA) }\end{array}$ & B. longum $\mathrm{MG} 1$ & $\begin{array}{l}\text { Expressed with two promoters from Bifidobacterium spp. GE65 } \\
\text { (sequence analysis revealed similarity with Lactobacillus johnsonii) }\end{array}$ & Ji et al. 2005 \\
\hline Glutamate decarboxylase & Rice & B. longum MG1 & Not known & Park et al. 2005a \\
\hline Flagellin $(f l i C)$ & $\begin{array}{l}\text { Salmonella } \\
\text { Typhimurium } \\
\text { ATCC14028 }\end{array}$ & B. animalis ATCC 27536 & Promoter of hup gene from B. longum & $\begin{array}{l}\text { Takata et al. 2006; Yamamoto } \\
\text { et al., } 2010\end{array}$ \\
\hline$\beta$-glucuronidase (gusA) & E. coli & B. longum $\mathrm{NCC} 2705$ & $\begin{array}{l}\text { Putative promoters of genes BL1363, BL1613 and BL1518 from } B \text {. } \\
\text { longum NCC2705 }\end{array}$ & Klijn et al. 2006 \\
\hline PTEN tumor suppressor & Human & B. longum L17 & Promoter region of hup gene from B. longum & Hou et al. 2006 \\
\hline Interleukin-10 (rhIL-10) & Human & B. longum ATCC15707 & $\begin{array}{l}\text { Promoter and terminator sequences from hup gene from B. longum } \\
\text { NCC2705 }\end{array}$ & Reyes Escogido et al. 2007 \\
\hline Interleukin-10 (hIL-10) & Human & B. breve UCC2003 & Promoters of hup and gap genes from B. longum & Khokhlova et al., 2010 \\
\hline$\beta$-glucuronidase (gusA) & E. coli (from pNZ272) & B. breve NCIMB 8807 & rRNA gene promoter from B. breve 8807 & Sangrador-Vegas et al. 2007 \\
\hline Luciferase (lucGR) & $\begin{array}{l}\text { Pyrophorus } \\
\text { plagiophthalamus }\end{array}$ & B. longum NCC2705 & Promoter from phage $\mathrm{T} 5$ & Guglielmetti et al. 2008 \\
\hline Cholesterol oxidase (choPA operon) & Streptomyces spp. & B. longum MG1 & 16S rRNA gene promoter from $B$. longum MG1 & Park et al. 2008 \\
\hline$\alpha$-1-arabinofuranosidase $(a b f B)$ & B. longum B667 & B. pseudocatenulatum M115 & Native & Álvarez-Martín et al. 2008 \\
\hline Bacterial luciferase (luxABCDE operon) & $\begin{array}{l}\text { Photorhabdus } \\
\text { luminescens }\end{array}$ & B. breve UCC2003 & $\begin{array}{l}\text { repC } \text { promoter from } B . \text { catenulatum plasmid } \mathrm{pBC} 1 \text { and promoter } \\
\text { Phelp from Listeria monocytogenes }\end{array}$ & Cronin et al. 2008 \\
\hline $\begin{array}{l}\text { Bile resistance mechanism BilE ( } b i l E \\
\text { operon) }\end{array}$ & $\begin{array}{l}\text { L. monocytogenes } \\
\text { EGD-e }\end{array}$ & B. breve UCC2003 & Native & Watson et al. 2008 \\
\hline $\begin{array}{l}\text { Synthetic human fibroblast growth } \\
\text { factor (FGF-2) fused with signal peptide } \\
\text { of Sec2 from B. breve UCC } 2003\end{array}$ & pkFGFB & B. breve UCC2003 & $\begin{array}{l}\text { Promoter and terminator regions of hup gene from B. longum } \\
\text { VMKB44 } \\
\text { Promoter/TIR of B. longum VMKB44 gene gap }\end{array}$ & Shkoporov et al. $2008 \mathrm{~b}$ \\
\hline Interferon- $\alpha 2 b$ & Human & B. longum ATCC 15707 & E. coli araBAD promoter from commercial vector $\mathrm{pBAD}$-gIIIA & $\begin{array}{l}\text { Deng et al. 2009; Yu et al., } \\
\text { 2010, } 2011\end{array}$ \\
\hline
\end{tabular}


Thymidine kinase

Granulocyte colony-stimulating factor

(GCSF)

Herpes simplex

B. infantis

B. longum

B. longum $\mathrm{NCC} 2705$

Human

Mouse tac promoter of commercial vector pGEX-5X-

Coliphage lambda $\mathrm{P}_{\mathrm{R}} \mathrm{P}_{\mathrm{L}}$ promoter regions

E. coli araBAD promoter

E. coli araBAD promoter from commercial vector pBAD-gIIIA
Tang et al. 2009

Zhu et al. 2009

Long et al. 2010

Yu et al., 2012 


\section{Type I}

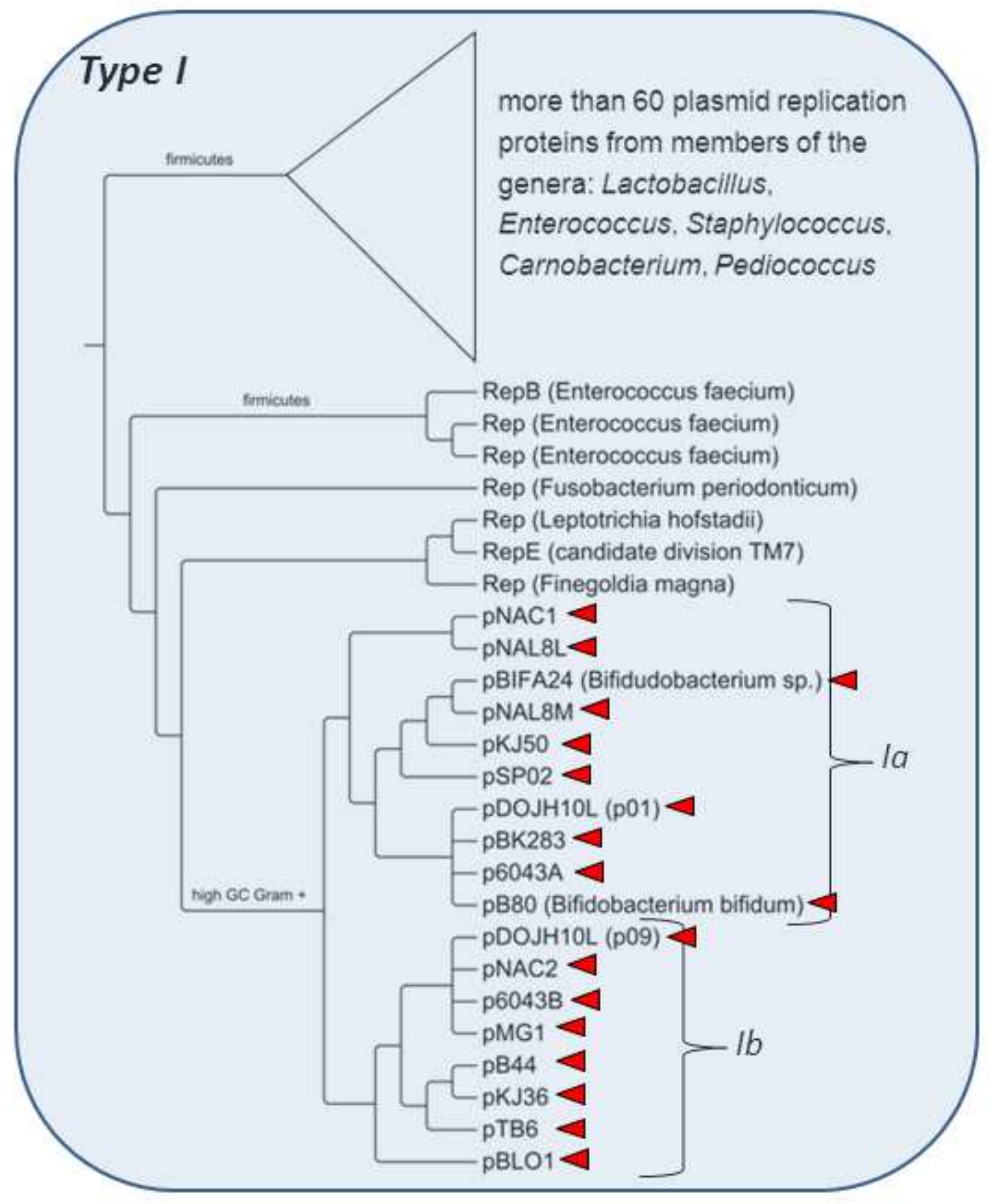

1381 


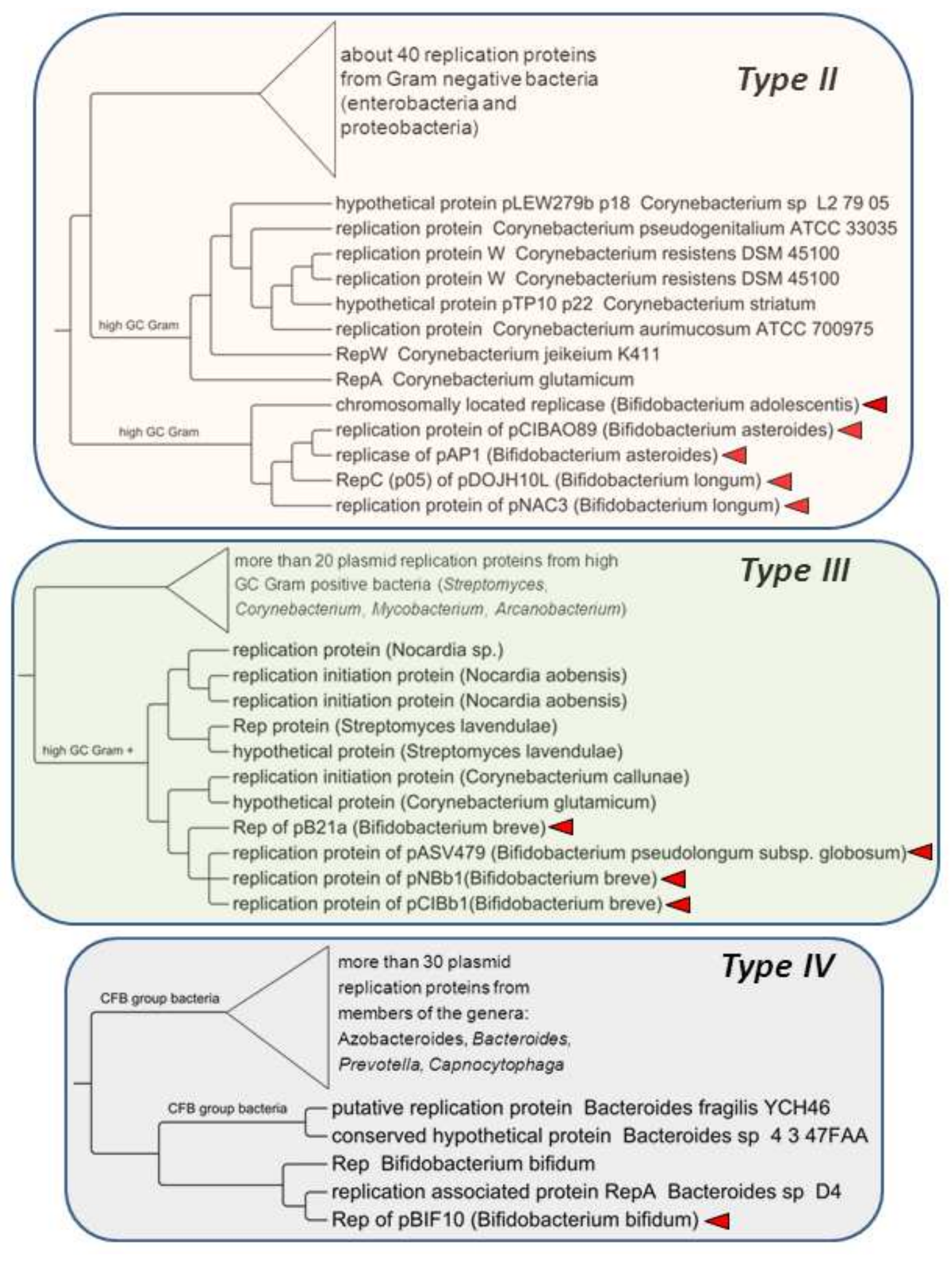




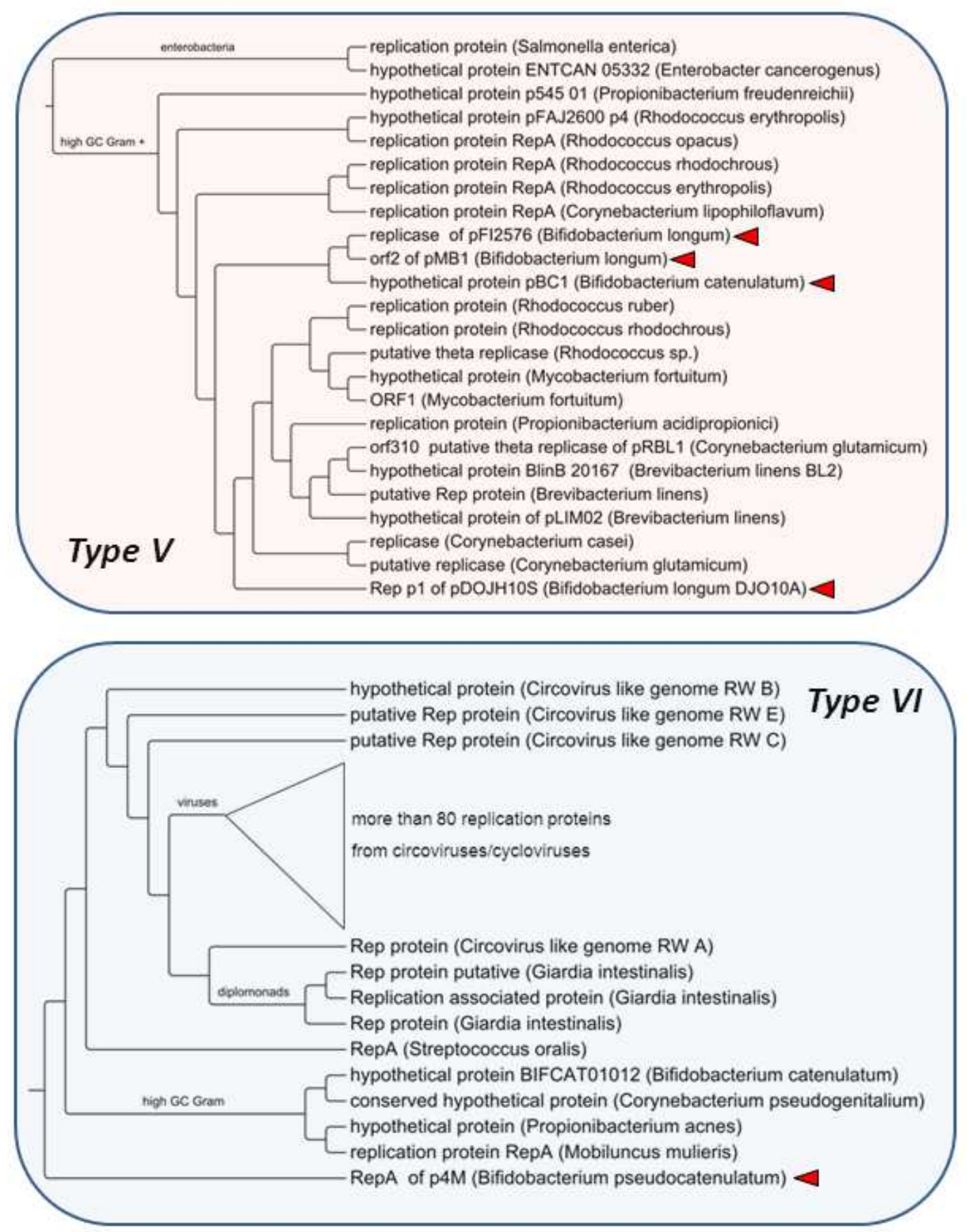

1383

1384 
1385 Fig. 2
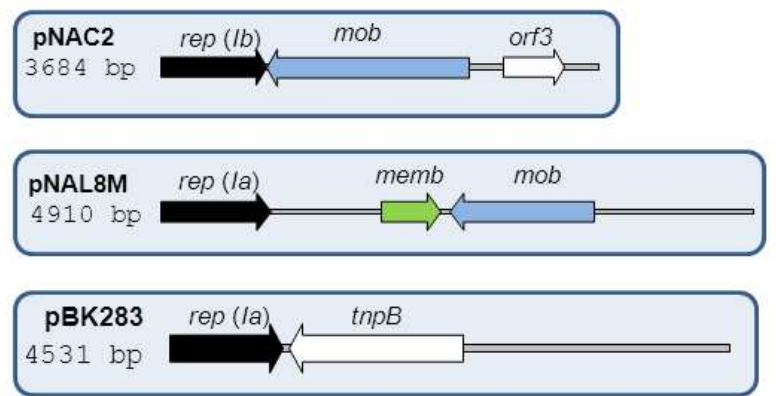

orf7 (bacteriocin?)

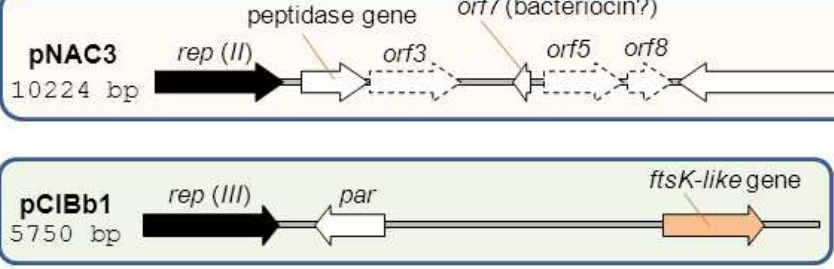

trw
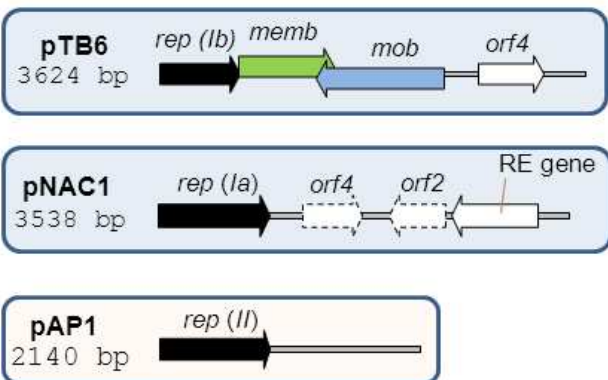

140 bp

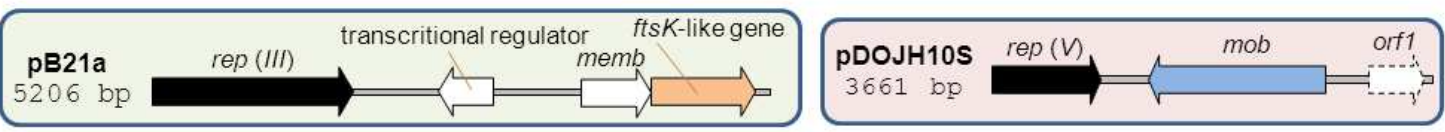

PBIF10 rep (IV)

1386

p48 $4 \mathrm{M}$ bp

1387 
Fig. 3

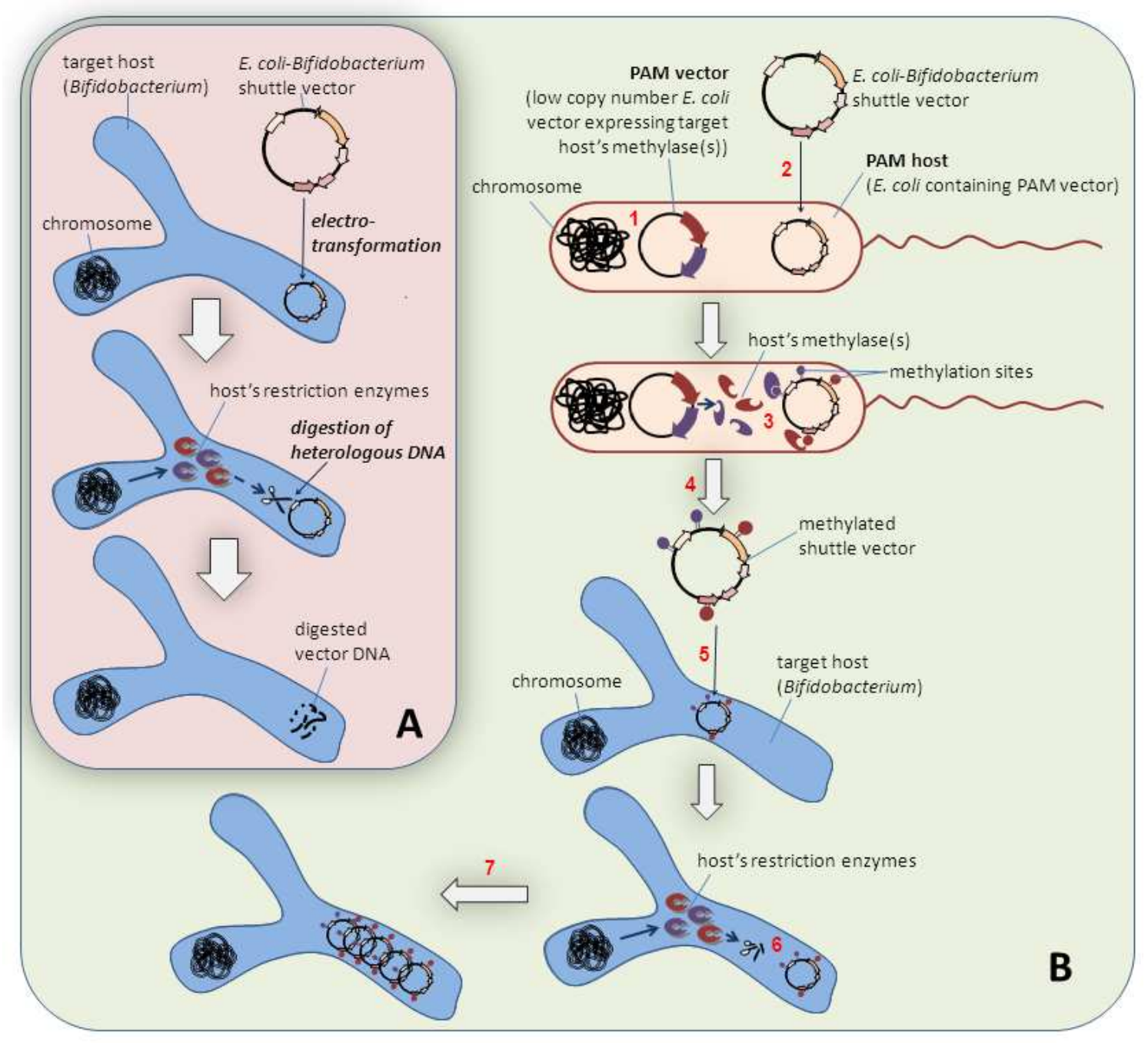

1389 